\title{
PANORAMA DE LA TEOLOGÍA DEL SACERDOCIO
}

DOI: https://doi.org/10.52039/seminarios.v55i194.453 ROMÁN SÁNCHEZ CHAMOSO1 ÍNDICE

1. El tema en el pasado inmediato ........................................................... 16

1.1. El tema antes del concilio ........................................................ 16

1.2. El tema en el concilio .............................................................. 17

1.3. El tema en el postconcilio .................................................... 18

1.4. El fenómeno de la crisis sacerdotal ........................................... 20

2. Frentes abiertos en la teología del sacerdocio .................................... 23

2.1. El manantial del sacerdocio ministerial ..................................... 23

2.2. El sacramento del orden revalorizado .................................... 24

2.3. Relacionalidad: clave integradora del sacerdocio ministerial ....... 27

2.4. Teología del presbiterio ......................................................... 29

2.5. Fraternidad sacramental ....................................................... 31

2.6. Espiritualidad propia y específica ............................................. 34

2.6.1. La espiritualidad como elemento teológico:
identidad y espiritualidad sacerdotal ......................... 34

2.6.2. Peculiaridad de la espiritualidad sacerdotal: en el ejercicio del ministerio .................................... 36

2.6.3. La peculiar ascesis sacerdotal ................................ 38

2.7. En la paradoja cristiana de la mediación ................................... 39

2.7.1. Cristo único mediador ........................................ 39

2.7.2. El hombre necesita mediadores ................................. 41

2.8. Desde Cristo, en la Iglesia, para la comunidad ............................ 42

3. Problemática pendiente .................................................................. 44

3.1. Presbiterio …...................................................................... 45

3.2. Episcopado y presbiterio ....................................................... 47

3.2.1. Historia de una relación accidentada .......................... 47

3.2.2. Sacerdos secundi ordinis ...................................... 50

3.3. Equilibro entre los munera del sacerdote ................................. 51

3.4. Hacia el nuevo tipo de sacerdote ............................................... 52

3.4.1. Del Sumo Sacerdote al Siervo de Yavé ....................... 52

3.4.2. Una búsqueda secular ......................................... 52

3.4.3. Perfil del nuevo tipo de sacerdote ............................. 53

3.5. Hacia una teología renovada del presbiterado ............................. 56

3.5.1. Teología del sacerdocio en camino ............................. 57

3.5.2. Apuntes para la renovada teología del sacerdocio ....... 58

1 Sacerdote Operario Diocesano. Salmantino y doctor en teología por la UPSA. Actualmente profesor en el seminario santa Rosa de Lima de Caracas y en el seminario Jesús Buen Pastor de Ciudad Bolívar, Venezuela. 
Se me ha invitado a participar en unas Jornadas de Reflexión sobre el Sacerdocio, acotando mi intervención al tema Panorama de la teología del sacerdocio. Voy a circunscribirme en mi exposición a los veinte últimos años, los que llevo en América Latina (Venezuela), donde he abordado el tema en la docencia y publicaciones, contando además con el trasfondo de mi presencia durante 32 años en el campo de la formación de seminaristas en Roma, Salamanca, Zaragoza y Caracas.

Los puntos que abordaré suponen una selección personal, y se podría objetar que tal selección pudo haberse hecho según otros criterios; admito que en la elección hecha por mi han podido entrar en juego factores poco convincentes para otros, pero sí puedo aseverar que no me he guiado por meros gustos personales o por determinadas afinidades ideológicas. Lo que si admito, ya de entrada, es que las tomas de postura del concilio Vaticano II y el posterior magisterio de la Iglesia sobre nuestro tema tienen para mi un peso específico, contando, además, con el desarrollo de la teología postconciliar.

\section{EL TEMA EN EL PASADO INMEDIATO}

\subsection{El tema antes del concilio}

La teología del sacerdocio antes del concilio Vaticano Il y que llega hasta sus puertas tiene a sus espaldas siglos de inmovilismo, está dominada por una cansina repetición de los manuales más extendidos. Hay una abundantísima literatura sacerdotal caracterizada por una notable perspectiva espiritual, jurídica y disciplinar, pero es escasa la teología sacerdotal propiamente dicha. Esto explica que se hubiera ido extendiendo un malestar difuso que aumentaba a partir de mediados del siglo XX. Las causas, en líneas generales, podían reducirse a que la novedad del sacerdocio cristiano quedaba seriamente comprometida por tres afluentes que desembocaban en la teología del sacerdocio: peso y vigencia del sacerdocio veterotestamentario, noción de sacerdocio de las religiones y el mimetismo de las estructuras socio-políticas. Esto significaba que la teología del sacerdocio era deudora en excesiva medida de factores exógenos al sacerdocio propiamente cristiano².

Con este exiguo equipamiento teológico se llega al concilio Vaticano II. Un dato significativo es el rechazo por clamorosa votación en contra que recibió el documento presentado al concilio para su estudio.

2 R. Sánchez Chamoso, Ministros de la Nueva Alianza. Teología del sacerdocio ministerial, CELAM, Bogotá 1993, 32-35 (En adelante: MNA). 


\subsection{El tema en el concilio}

Se ha hecho notar que el tema sobre los sacerdotes entra tarde en el concilio y por una puerta lateral ${ }^{3}$. Es el documento que llega al concilio menos claramente definido 4 .

El tema de la teología del sacerdocio en el Vaticano II hay que situarlo teológicamente entre el tema del episcopado y el del laicado, y la referencia a éstos es significativa pues el desarrollo teológico del sacerdocio es notablemente inferior al que se da al episcopado y al laicado5. Es idea ampliamente compartida entre los teólogos que la teología del presbiterado en el Vaticano II no ha estado al nivel de la teología del episcopado y del laicado6. Argumentamos con datos de los mismos documentos conciliares:

- Conjunto de los documentos conciliares: al episcopado se dedican 10 números de LG y el decreto CD; al laicado, 9 números de LG (cap. IV) y el decreto $A A$; al presbiterado, 1 número de LG y el decreto PO.

. LG, el documento principal del Vaticano II, dedica 10 números del cap. III al episcopado, 9 números al laicado y 1 número, el 28 , al

3 Se decide abordar el tema a fines de la primera sesión conciliar (diciembre de 1962) ante voces de alarma por el silencio sobre los sacerdotes. La teología del sacerdocio que elabora el concilio queda reflejada en LG 28 y en los decretos PO y OT.

Sucinta historia de la redacción de $\mathrm{PO}$, el documento más directamente pertinente a nuestro tema. Es trabajado en buena parte en las intersesiones del concilio. La primera redacción se titula De clericis; en febrero de 1963 se hace la segunda redacción, y en octubre se elabora el tercer texto titulado De sacerdotibus. En 1964 se hace la cuarta redacción, en octubre la quinta y en noviembre de la sexta, con el mismo título, que recoge la profunda transformación sufrida en el proceso redaccional y que lleva por título De ministerio et vita presbyterorum. Este texto se estudia entre la $3^{a}$ y $4^{a}$ etapa conciliar, hasta abril de 1965. Por fin, la séptima redacción se presenta y discute en octubre de 1965. Fruto de la discusión es la redacción octava enmendada, sometida a últimos retoques, y que es votada por el concilio el 4 de diciembre de 1965. El decreto PO es promulgado solemnemente por Pablo VI el 7 de diciembre, con 4 votos negativos de 2394 votantes. Por tanto, es uno de los documentos conciliares aprobados más tarde en la última sesión pública.

4 Cf. M. Velati, Las vicisitudes del esquema sobre los sacerdotes en G. Alberigo (dir), Historia del concilio Vaticano II, V, Sígueme-Peeters, Salamanca-Leuven 2008, 218247.

5 Lo que en opinión de muchos significa que se está aquí anidando la crisis sacerdotal que estallará una vez terminado el concilio.

6 El Vaticano II redefinió ciertamente de nuevo la Iglesia, los laicos, pero falta la redefinición del sacerdote (P. M. Zulehner, Las vocaciones pastorales antiguas y nuevas 
presbiterado.

- LG cap. III: constitución jerárquica de la Iglesia o ministerio ordenado: de 12 números, 10 son para el episcopado, 1 para el presbiterado (el 28) y 1 para el diaconado (el 29)

Estos datos estadísticos hablan por sí solos. El presbiterado queda situado entre episcopado y laicado, un hecho familiar en la historia, pero, dada la relación entre ellos, cuando uno cambia repercute necesariamente en los otros. De hecho, el gran desarrollo de la teología del episcopado y del laicado tenía que incidir fuertemente en la del presbiterado.

Otro tema del concilio Vaticano II que nos interesa es la terminología para expresar el sujeto del ministerio ordenado. Se recurre a un rico y variado manojo de descripciones teológicas, que ponen de manifiesto la complejidad (riqueza y variedad) de facetas que encierra ${ }^{7}$. Pero es significativo el proceso que sigue el concilio para dar nombre al ministro ordenado 8 .

\subsection{El tema en el postconcilio}

En nuestra exposición consideramos el concilio y el postconcilio como un blo-

en la Iglesia en Seminarios 23 (1977) 203) Con todo, hay que afirmar la independencia y el aporte peculiar del Vaticano II, que no parece que se muestre muy deudor de cualquier teología precedente sobre el ministerio y el sacerdocio (S. Dianich, Teología del ministerio ordenado. Una interpretación eclesiológica, Paulinas, Madrid 1988, 77).

7 Cfr. MNA, 22.

8MNA, 35-37: se sigue fundamentalmente este itinerario: sacerdote, pastor, presbítero. Analizando los documentos:

SC, que fue le primer documento elaborado por el concilio y se ocupa del ministerio cultual: domina el término sacerdote, le sigue el de pastor.

LG, que se ocupa de la Iglesia en su globalidad: domina pastor, le sigue presbítero y sacerdote.

CD, que se ocupa del episcopado: domina sacerdote, sigue pastor y presbítero.

$\mathrm{PO}$, el decreto sobre el presbiterado: domina presbítero, que además da título al documento, le sigue pastor y sacerdote.

OT, sobre la formación sacerdotal: domina sacerdote.

De estos datos se sigue que el concilio carece de una terminología uniforme, pero se advierte el tránsito paulatino de la terminología tradicional (sacerdote) a otra bíblica y pastoral como presbítero y pastor. Indudablemente, como bien sabemos, la terminología que empleamos no es neutra semánticamente, y la aquí referida apunta a una determinada naturaleza del ministerio ordenado. 
que. Tengamos en cuenta que el concilio llega a una postura madura y consolidada en algunos temas o puntos, en otros casos significa un aporte ocasional al hilo de la reflexión y en otros significa sencillamente un horizonte hacia el que se nos invita a caminar, abriendo el camino con unos primeros pasos. La teología del sacerdocio del postconcilio se ubica en esta senda conciliar, avanzando en la dirección señalada por el Vaticano II y llegando a veces a madurar temas solo inicialmente tratados.

Se reconocen límites del Vaticano II en nuestro tema. No faltan las críticas a la postura del concilio en el sentido de que había superado tan solo parcialmente la teología tradicional acerca del presbiterado 9 . Algunos comentarios hacen constar que, incluso en la última discusión del documento, se hallaba muy difundido el descontento dentro del aula conciliar ${ }^{10}$.Vamos a señalar tres límites del concilio:

- El Vaticano II aborda el presbiterado en cierto sentido de forma indirecta en cuanto que lo plantea a través de un prisma teológico sectorial: el episcopado. Por tanto, es un abordaje parcial, en el sentido de que se hace desde uno de los ministerios. Queda, pues, pendiente un planteamiento directo e integral del presbiterado, que tiene múltiples referencias (y no solo la del episcopado), que deben ser tenidas en cuenta ${ }^{11}$.

- El enfoque conciliar del presbiterado es eminentemente intraeclesial, lo que no ha permitido un planteamiento suficientemente sensible para afrontar las relaciones entre Iglesia y mundo. Esto explica que temáticas que han tomado auge después del concilio (como la secularización, el anticlericalismo, la teología política y de la liberación, la cultura de la increencia...) no hallarán siempre en la doctrina conciliar sobre el ministerio sacerdotal las oportunas respuestas o las pistas para caminar. Estas cuestiones aplazadas van a tener un peso determinante en la crisis sacerdotal, que estalla apenas terminado el concilio.

- El concilio ha situado en una postura angosta y molesta la figura del presbítero entre las figuras crecidas teológicamente del obispo y del laico; estos ministerios colaterales al del presbítero hacen que

9 Cfr. C. Duquoc, La riforma dei chierici en G. Alberigo-J. P. Jossua (eds), II Vaticano Il e la Chiesa, Brescia 1985, 399-414.

10 Cfr. M. Velati, a.c., 225; Id., La formación de los sacerdotes en G. Alberigo (dir), Historia del concilio Vaticano II, V, Sígueme-Peeters, Salamanca-Lauven 2008, $185-$ 191.

11 Nos ocuparemos del tema con cierta amplitud al tratar de los puntos pendientes en nuestra materia. 
éste vea reducida su estatura. Hay aquí otra de las causas de la mencionada crisis sacerdotal.

Por consiguiente, la teología postconciliar sobre el sacerdocio se desenvuelve en este clima de logros alcanzados por el concilio y de temas aplazados y que se hace ineludible afrontar ${ }^{12}$.

El Vaticano II fue un punto de partida también en lo referente a los pronunciamientos de la Iglesia sobre el sacerdocio que nos sitúa ante un itinerario de búsqueda13. La misma Iglesia recuerda las principales intervenciones magisteriales sobre el sacerdocio en el postconcilio, como los Sínodos de los obispos de 1967, de 1971, de 1974, de 1990, así como la Ratio Fundamentalis Institutionis Sacerdotalis de 197014, itinerario que se ve coronado con el espléndido documento de 1992 PDV, feliz glosa de la teología conciliar y de lo mejor de la postconciliar sobre el sacerdocio.

La teología postconciliar sobre el sacerdocio es ciertamente caudalosa y variada, rica y esclarecedora, caminando paso a paso en la puesta al día del tema.

\subsection{El fenómeno de la crisis sacerdotal}

Apenas terminado el concilio, nos sorprende la irrupción en toda la Iglesia de la crisis sacerdotal. El hecho es innegable y desconcertante. Escuchemos este testimonio ciertamente autorizado del inmediato postconcilio:

En nuestros días, son muchos los presbíteros que pasan por una grave sensación de malestar y de inseguridad. Para algunos, el malestar es tal que conlleva una crítica sistemática no solamente al estatuto sociológico del presbítero en el mundo de nuestros días, sino incluso de la misma concepción del ministerio sacerdotal. Es una crisis que concierne a la identidad del presbitero ${ }^{15}$.

12 El mismo magisterio declara: En estos últimos años y desde varias partes se ha insistido en la necesidad de volver sobre el tema del sacerdocio, afrontándolo desde un punto de vista relativamente nuevo y más adecuado a las presentes circunstancias eclesiales y culturales (Juan Pablo II, Exh. apost. Pastores dabo vobis, n. 3 (En adelante: PDV).

13 La Iglesia ha afrontado en muchas ocasiones los problemas de la vida, ministerio y formación de los sacerdotes (Juan Pablo II, PDV, n. 3).

14 AAS 62 (1970) 321-384.

15 Commission Internationale de Théologie, Le ministère sacerdotal. Rapport, Cerf, Paris 1971, 9. Cf. J. Sahagún Lucas, Crisis sacerdotal. La problemática sacerdotal de nuestro tiempo, Fontanella-Marova, Barcelona-Madrid 1975. El fenómeno es abordado más directamente por el magisterio en el Sínodo de los Obispos de 1971, El 
Quizá la figura eclesial más cuestionada después del Vaticano II ha sido la del sacerdote, lo que ha contribuido a su desdibujamiento y cuestionamiento. El tema puede enfocarse sociológicamente, pastoralmente o teológicamente. Sin duda, la vertiente más llamativa y divulgada es la sociológica, consistente en los numerosos abandonos del ministerio, y que se convierte en tema del gran público. Pastoralmente ha supuesto numerosos y difíciles desajustes en el interior de la Iglesia al disminuir notablemente el número de sus sacerdotes, pero lo que debe interesarnos, sobre todo, es la vertiente teológica: ¿Qué es, a qué se debe el problema, cómo explicarlo?

El fenómeno se vincula de alguna forma con el Vaticano II, pero en sentido diverso para unos u otros: mientras que para algunos es propter Concilium, para otros se trata únicamente de algo post Concilium ${ }^{16}$. En realidad, el hecho tiene muchas caras, se dan diversas explicaciones y formulaciones de él. Vamos por ahora a limitarnos a una pregunta: ¿es una crisis de la teología del sacerdocio como indican algunas publicaciones ${ }^{17}$ o es una crisis del rol del sacerdote en la sociedad actual ${ }^{18}$. Con todo, aun cuando se tratara de la crisis del estatuto sociológico del sacerdocio, dado que el sacerdocio no es una mera profesión que se puede cambiar por otra, sino una vocación en la que está embarcada a fondo toda la persona, la crisis incide de lleno en la persona del presbítero. Por tanto, si entra en crisis el rol, entra en crisis el sujeto del rol.

El Vaticano II removió profundamente las bases de la teología del sacerdocio al proponer un nuevo tipo de Iglesia, lo que necesariamente conlleva, como enseña la historia, una revisión a fondo de los ministerios, ya que éstos son la vertiente operativa de la Iglesia. El fenómeno se tradujo inmediatamente en la pregunta por un nuevo tipo de sacerdote ${ }^{19}$. Estamos ante una búsque-

sacerdocio ministerial. Documentos, Sígueme, Salamanca 1972, y por el Sínodo Extraordinario de 1985, El Vaticano II, don de Dios. A los veinte años del final del concilio, PPC, Madrid 1986.

16 Ésta última es la interpretación del Sínodo Extraordinario de los Obispos de 1985.

17 Ver el texto de la Nota 14, de la Commission Internationale de Théologie.

${ }^{18}$ Así el detallado estudio empírico sobre deserciones sacerdotales de E. Colagiovanni, Crisi vere e false nel ruolo del prete oggi. Uno studio sociologico a livello mondiale, Città Nuova Editrice, Roma 1973.

19 Son indicativos algunos títulos: A. Ancel, Un nuevo tipo de sacerdote en AA.VV., Concilio vivo, Ancora, Milano 1967, 214-223; Id., II sacerdote nel mondo contemporaneo en AA.VV., I sacerdoti nel pensiero del Vaticano II, Roma 1966; G. M. Garrone, II prete de domani, Leumann, Torino 1969; T. Cloin, Un nuevo tipo de sacerdote en Medellin 3 (1975) 373-379; R. Etchegaray, Verso una nueva immagine del sacerdote en AA.VV., Il prete per gli uomini d'oggi, A.V.E, Roma 1975; F. Urbina de Quintana, Hacia una nueva figura histórica del ministerio, EDICE, Valencia 1974. 
da, no propiamente ante una crisis; es una reflexión con una nueva actitud de carácter teológico y antropológico a un tiempo, pues se puede decir que, después del Vaticano II, los católicos no vemos ya a la Iglesia y al mundo exactamente igual que antes ${ }^{20}$, se abre paso una nueva actitud teológica que no se limita a repetir los planteamientos del pasado.

Otro hecho llamativo, apenas terminado el concilio, son las preguntas directas sobre el sacerdote: ¿Sacerdote, para qué?, ¿sacerdote, cómo?, ¿sacerdote, quiénes?21. Estos interrogantes nos indican que el cuestionamiento concierne de lleno al sacerdote.

¿De qué clase de crisis se trata? Creemos que es más una crisis de misión que una crisis de identidad propiamente dicha. No resultaba fácil digerir el profundo giro eclesial operado en el concilio, lo que descolocó a muchos que habían hecho su opción vocacional en otro tipo de Iglesia y para una acción ministerial muy distinta de la que pide la Iglesia del Vaticano II. Por otra parte, el pujante laicado iba ocupando lugares y asumiendo tareas hasta ahora llevadas por el sacerdote. En definitiva, el para qué del ministerio sacerdotal se había desplazado hasta el punto de que muchos sacerdotes comenzaron a verse como extraños.

Las causas originantes de la crisis sacerdotal son múltiples y muy diversas, y son tanto endógenas como exógenas, es decir, por una parte proceden del interior de la Iglesia y de la teología y, por otra parte, son originadas por instancias seculares 22 . El hecho palpable e hiriente es la necesidad de buscar una nueva imagen del sacerdote, urgidos aún más por la crisis de los años que siguieron al concilio23.

20 H. Carrier, La aportación del concilio a la cultura en R. Latourelle (ed), Vaticano II: Balance y perspectiva. Veinticinco años después (1962-1987), Sígueme, Salamanca 1989, 1087-1093.

21 J. Ma . Castillo, Los nuevos ministros. La Iglesia será ella misma cuando tenga su centro en los laicos en Sal Terrae 65 (1977) 3-21; P. Guilinot, Fin d'une Eglise clericale, Cerf, Paris 1969; R. Laurentin, Nouveaux ministéres et fin du clergé devant le III Synode, Seuil, Paris 1971; R. Dubert, Comunidades sin sacerdote en Sal Terrae 63 (1975) 284-289.

22 Cf. MNA, 42-62.

23 Cerramos el apartado con el testimonio de un teólogo cualificado en nuestros temas: Nuestro tiempo está a la búsqueda de una 'nueva imagen' del sacerdote y del obispo. Por imagen entendemos aquí la identidad, la significación y el valor socio-psicológico reconocidos a una persona que ejerce una función en un grupo... La modificación de la identidad de la imagen es un fenómeno común en medio de los profundos trastornos que hoy experimenta el occidente (P. Fransen, voz Órdenes en K. Rahner (dir), Sacramentum Mundi, 5, Herder, Barcelona 1969-1976, col. 24s.) 


\section{FRENTES ABIERTOS EN LA TEOLOGÍA DEL SACERDOCIO}

Vamos a considerar los capítulos fundamentales que, a partir del Vaticano II, se han destacado hasta nuestros días. Estos frentes abiertos son más o menos nuevos, a veces se trata de temas clásicos, pero repensados y actualizados a la altura de la Iglesia y de la teología de nuestros días.

Puede decirse que nos hallamos en una situación caracterizada al mismo tiempo por la crisis y apología del sacerdocio, es decir, se ha dado una profunda revisión de la teología tradicional y simultáneamente una elaboración de las diversas líneas de una renovada teología del sacerdocio. Al seleccionar una serie de temas, debemos dejar constancia que están constelados de otros necesariamente conectados e importantes para la configuración de la teología del sacerdocio hoy; estos puntos serán abordados solo tangencialmente.

\subsection{El manantial del sacerdocio ministerial}

Comencemos recordando algo fundamental y que no siempre se ha tenido en cuenta o se ha dado por supuesto precipitadamente: nuestro sacerdocio ministerial no procede del mundo de las religiones, ni de la comunidad, ni del ministro ordenante, sino solo y únicamente del Cristo Sacerdote del Nuevo Testamento, con referencia particular al ministerio originario de los apóstoles, en quienes se prolonga y manifiesta el sacerdocio de Cristo. El cauce por el que se accede a este sacerdocio es el sacramento del orden.

Sacerdote de Jesucristo: es el título primero, el nombre más certero para designar el sacerdocio ordenado. Cristo es la única fuente, origen, raíz, paradigma ${ }^{24}$, de cuyo sacerdocio participa de modos distintos todo sacerdocio cristiano, tanto el bautismal como el ministerial.

Vamos a ocuparnos de un capítulo particular del Vaticano II que ha alterado el planteamiento de nuestro tema y es hoy referencia obligada. El concilio, en su giro teológico, se refiere a nuestro tema de forma indirecta, o sea, a través de la teología del episcopado. La estrecha relación entre episcopado y presbiterado recorre toda la historia de la teología, pero hoy presenta perfiles nuevos. Ahora la relación es con un episcopado no entendido como una dignidad, sino teológicamente revalorizado al ser proclamada su sacramentalidad (LG 21), y ser entendido no solo como el grado superior del sacramento del orden con competencias exclusivas (Trento), sino como la plenitud del sacramento del orden y el culmen del ministerio sagrado (G 21b; 26a; CD 15; PO 7b). El episcopado así entendido teológicamente es el epicentro y referencia inmediata de la teología del presbiterado. Éste y el diaconado participan también del sacramento del orden, pero en grado inferior, por lo que deben tener en cuenta la instancia que posee el sacramento

24 La teología actual del sacerdocio podemos decir que es unánime en este punto, ratificado y enfatizado por PDV, cap. II. 
en plenitud. El sacerdocio del presbítero, que no es plenitud, sino participación en grado subordinado ( $\mathrm{PO} 2 \mathrm{~b}$ ), guarda una necesaria referencia al ministerio ordenado que ostenta esa plenitud.

Este aporte teológico básico ha llevado a repensar la teología del presbiterado. Éste, repite en diversos registros el Vaticano II, se entiende con el episcopado al fondo. Esto ha supuesto un giro fundamental en la teología del sacerdocio. Hasta el Vaticano II, el sacerdocio ordenado se entendía a partir de la noción común de sacerdocio, propio de las religiones, y, desde ese presupuesto, obispo y presbítero participaban por igual del sacerdocio que les confería el sacramento del orden, o sea, compartían la potestas ordinis, y la diferencia entre obispo y presbítero se debía a la diferente potestas iurisdictionis, más amplia en el obispo. Así lo sancionó Trento 25 y así llegó hasta el Vaticano II; se carecía de una sólida teología del episcopado (al tiempo que se tenía una teología amplísima del primado), que ha sido el gran aporte teológico del Vaticano II, especialmente el punto clave de la sacramentalidad del episcopado (LG 21) y su consecuente colegialidad (LG 22).

Este aporte teológico básico ha llevado a una nueva teología del presbiterado. Éste, repite en varios registros el Vaticano II, se debe entender en relación con aquel ministerio que ostenta la plenitud del sacramento del orden y la cumbre del ministerio sagrado. El sacerdocio ministerial se entiende desde el episcopado, no desde la noción común de sacerdocio. El giro operado aquí por el concilio es cualitativo.

Hasta aquí los datos teológicos básicos debidos al Vaticano II, con el gran cambio que ello supone. Pero con ello no se ha dicho todo, y a la teología le queda una inexcusable tarea, se hace necesario aportar importantes matices. En rigor, el episcopado no puede entenderse como la fuente y raíz del presbiterado; hay un dato previo a ambos: episcopado y presbiterado son lo que son en virtud del sacramento del orden, participado por ambos en diverso grado. El sacramento, y solo el sacramento, es propiamente el manantial del presbiterado. Por tanto, corresponde a la teología explicar cómo se debe entender que el presbiterado proceda desde el episcopado. ¿Qué alcance, qué sentido hay que darle a ese desde? Más adelante, en la tercera parte de este trabajo sobre la problemática pendiente, abordaremos este punto.

\subsection{El sacramento del orden revalorizado}

En la medida que se ha adentrado el planteamiento del ministerio ordenado en el sacramento del orden, ha ganado densidad teológica y ha ofrecido

25 Trento enseña la superioridad del obispo sobre el presbítero basado en las facultades concedidas solamente a los obispos (DS 1768.1777), pero no enseña que esa superioridad sea de iure divino. 
bases nuevas y sólidas a la teología del ministerio sacerdotal. El aporte del Vaticano II a este respecto ha sido fundamental, de forma que, cuestiones que se dilucidaban desde el derecho canónico o desde el magisterio de la Iglesia se esclarecen ahora en base al sacramento del orden. Vemos algunos puntos indicadores del profundo cambio operado:

\section{Los 'tria munera' de episcopado y presbiterado}

Hasta el Vaticano II, el munus sanctificandi se entendía como efecto del sacramento del orden (potestas ordinis), pero los munera regendi et docendi tenían procedencia extrasacramental. El concilio Vaticano II ha dado un paso adelante fundamental: los tria munera del obispo nacen del sacramento del orden ${ }^{26}$, al igual que los tria munera del presbítero ${ }^{27 .}$

\section{Adscripción al colegio episcopal y al presbiterio}

Los obispos son hechos miembros del colegio episcopal no por un nombramiento o designación eclesiástica, sino por la sagrada ordenación 28 , y del mismo modo son adscritos al presbiterio los presbíteros 29 . Por consiguiente, tanto el colegio episcopal, la colegialidad episcopal y el presbiterio (fraternidad sacramental: PO 7a) son efecto del sacramento del orden.

26 La consagración episcopal, junto con el oficio de santificar, confiere también los oficios de enseñar y de regir (LG 21a; cf. CD 3a).

27 Por el don del Espíritu Santo que se ha dado a los presbíteros en la sagrada ordenación, los obispos los tienen como colaboradores y consejeros necesarios en el ministerio y oficio de enseñar, santificar y apacentar al pueblo de Dios (PO 7a). Los presbiteros, en virtud del sacramento del orden, han sido consagrados como verdaderos sacerdotes del Nuevo Testamento a imagen de Cristo, sumo y eterno sacerdote, para predicar el Evangelio, apacentar a los fieles y para celebrar el culto divino (LG 28a).

28 Uno es constituido miembro del cuerpo episcopal en virtud de la consagración sacramental, esto manifiesta la naturaleza y la forma colegial del orden episcopal (LG 22a).

29 En virtud de la común ordenación sagrada y de la común misión, todos los presbíteros se unen entre sí en íntima fraternidad (LG 28c), y forman, junto con su obispo, un solo presbiterio (LG 28b), los presbíteros, constituidos por la ordenación en el orden del presbiterado, se unen todos entre si por íntima fraternidad sacramental (PO 8a) Las consecuencias pastorales que de aquí se derivan son fundamentales: Ningún presbitero puede cumplir cabalmente su misión aislado y como por su cuenta (PO 7c), y cf. la enérgica formulación de PDV, n. 17. 


\section{Virtudes del presbítero}

La aspiración a la perfección del presbítero se remonta también al sacramento ${ }^{30}$. La peculiar obediencia presbiteral se asienta en definitiva en el sacramento del orden ${ }^{31}$.

\section{Espiritualidad}

El presbítero tiene una espiritualidad propia y específica que se asienta en el ejercicio del ministerio de los tria munera ${ }^{32}$.

\section{Relación simultánea con Cristo y con la Iglesia}

Otro efecto destacado del sacramento del orden es que anuda en el sujeto ordenado la relación con Cristo y, al mismo tiempo, con la Iglesia de manera inseparable, ambas necesarias ${ }^{33}$. En la misma ordenación sacramental, Cristo y la Iglesia envían al sujeto ordenado para ejercer una función vicaria en nombre de ambos. En una palabra, el ministerio sacerdotal es el ministerio de la misma Iglesia (PO 15b). El origen del ministerio presbiteral ha de buscarse en el origen mismo de la Iglesia ${ }^{34}$. La dimensión eclesiológica está ampliamente subrayada: el sacerdote está enclavado en la Iglesia misterio, comunión y misión 35 , está puesto al frente de la Iglesia 36 , como pastor de la Iglesia 37 y guía del pueblo de Dios (PO 22c) y para la edificación de la Iglesia (PO 6a)

30 Los sacerdotes están obligados de manera especial a alcanzar la perfección, ya que, consagrados de manera nueva a Cristo por la recepción del orden, se convierten en instrumentos vivos de Cristo (PO 12a).

31 Obediencia sacerdotal que se funda en la participación misma del ministerio episcopal, y que se confiere a los presbiteros en el sacramento del orden y la misión canónica (PO 7b).

32 Los presbiteros conseguirán de manera propia la santidad ejerciendo sincera e incansablemente sus ministerios en el espíritu de Cristo, ministerios que son fruto del sacramento del orden (PO 13).

33 Juan Pablo llega a hablar de mutua inmanencia (PDV, n. 16a) La relación del sacerdocio con Cristo y con la Iglesia, en virtud de la unción sacramental (PDV, n. 16e) Relación, por tanto simultánea, porque en cuanto misterio, la Iglesia está esencialmente relacionada con Jesucristo, es su plenitud, su cuerpo y su esposa. Es el signo y el memorial vivo de su presencia permanente y de su acción entre nosotros y para nosotros (PDV, n. 18d).

34 Cf. Comisión Episcopal del Clero, Sacerdotes para evangelizar, EDICE, Madrid 1987, n. 59.

35 PDV, nn. 12.59.73.

36 PDV, n. $16 b$.

37 PDV, nn. 15a-b; 22b. 


\subsection{Relacionalidad: \\ clave integradora de la teología del sacerdocio ministerial}

La teología del sacerdocio ha sentado tradicionalmente sus bases en los conceptos teológicos de sacramentalidad y ministerialidad38; según la preferencia por un concepto u otro se obtendrá una teología de corte cristológico o eclesiológico 39 . Ambos conceptos son básicos y esenciales, pero la teología asentada sobre cada uno de ellos será necesariamente parcial e incompleta, no podrá reflejar la verdadera naturaleza y riqueza del sacerdocio ordenado. Se ve, pues, la necesidad de un foco que salve por igual la opción cristológica y la eclesiológica.

Por otra parte, el sacerdocio no es un en si ni un para si, consistente en sí mismo y autosuficiente, que se pueda entender desde sí mismo, sino que es más bien algo relativo o referente a otras realidades teológicas de primer orden.

Por tanto, es necesario abordar un planteamiento integrador e inclusivo, planteamiento capaz de conjugar y hacer justicia a las diversas vertientes del sacerdocio ministerial y a la riqueza que encierra, y esto se ha logrado mediante el concepto o clave de relacionalidad 40 . Ésta nos proporciona una ventaja metodológica sobre sacramentalidad y ministerialidad, en el sentido de que no excluye a ninguna de ellas que siguen siendo fundamentales $\mathrm{y}$, por otra parte, pone de manifiesto la riqueza del sacerdocio ${ }^{41}$.

La relacionalidad ha adquirido en la teología postconciliar del sacerdocio un

38 Sobre esta base se fragua la terminología de sacerdocio ministerial (que enfatiza el sustantivo sacerdocio y con él el sacramento y adjetiva el ministerio) y de ministerio sacerdotal (que enfatiza o sustantiva el ministerio y adjetiva el sacerdocio), aunque en el lenguaje común podemos usar ambas expresiones como intercambiables, en manera alguna hay que entenderlas como alternativa; lo sacerdotal y lo misionero, sacramento y misión son ejes esenciales de la teología del sacerdocio. Ésta es la visión y el valor del Vaticano II, que tiene en cuenta la globalidad del sacerdocio, que incluye sacramento y misión; se sale así al paso del proceso reductivo, siempre acechante en la Iglesia (Cf. MNA, 430-433), que prioriza uno de los polos a costa del otro: la ontologización del sacerdocio o bien la ministerialidad del mismo (Cf. H. Denis, Les prêtres, Paris 1968, 193-232: ve en Trento la opción por el polo o foco sacerdotalsacramental y en el Vaticano II el misionero-eclesiológico)

39 Cf. MNA, 432-433.

40 Nos hemos ocupado del tema en MNA, 110-112.439-446 y en Iglesia-comunión e Iglesia ministerial. Comunión -Ministerio eclesial -Presbiterio, IUSI, Caracas 1997, 353-354 (En adelante: ICIM).

41 Cf. MNA, 434-439. 
papel determinante y clarificador para articular internamente la teología del sacerdocio. El sacerdote es un ser eminentemente relacional ${ }^{42}$, se entiende y existe en función de otras grandes realidades teológicas y a partir de ellas recibe diversos nombres. Esta idea está ganando terreno a la hora de comprender al sacerdote, aportando un importante elemento de equilibrio que evita la polarización en alguno de los polos: sacramentalidad o ministerialidad, acentuación cristológica o eclesial.

EI Vaticano II nos ha proporcionado los elementos para elaborar la teología del sacerdocio con la clave de la relacionalidad. Por tanto, sacramentalidad, ministerialidad y relacionalidad son los ejes vertebrantes y los pilares sobre los que se levanta la teología del sacerdocio en el Vaticano II, aunque el concilio no pudo elaborar dicha teología. En la línea abierta por el Vaticano II, ha continuado el magisterio y la reflexión teológica postconciliar, siendo PDV la clave de arco de la construcción, al ser la mejor glosa y la sanción oficial del mismo concilio, al mismo tiempo que incorpora los mejores aportes de la teología postconciliar sobre nuestro tema.

En efecto, PDV nos presenta genialmente el sacerdote como una red de relaciones, particularizando esta relación con puntos teológicos básicos ${ }^{43}$. Ello no significa que todas las referencias deban ser puestas al mismo nivel, o que gocen del mismo rango teológico, pero la afirmación troncal es que el sacerdote es un ser relacional. Se ha roto el secular aislamiento 44 en que se debatía la teología del sacerdocio al introducir esta red de relaciones, un tejido de conexiones que hacen posible una visión integral del sacerdocio. Nos referimos aquí únicamente a las relaciones vinculadas al sacramento del orden y con valencia ministerial-salvífica, no a las relaciones que el sacerdote tiene como simple ser humano. El sacramento crea en el ordenado un alma de comunión, el Espíritu Santo hace del sacerdote un ser-en-relación.

El ser para Dios del sacerdote se articula y despliega en un tejido de relaciones que dan rostro y concretan esa entrega total a Dios. De esta forma, se ha construido el siguiente cuadro abarcante de las relaciones del presbiterado que son ejes estructurales del mismo: relación o referencia a la Trinidad (hombre de Dios), a Cristo Sacerdote (sacerdote de Jesucristo), a la Iglesia o ministerio eclesial (ministro de la Iglesia), al ministerio apostólico encarnado en el episcopado (cooperador del orden episcopal), a la comunidad (pastor del pueblo de Dios), a los demás sacerdotes (co-presbítero ${ }^{45}$. Se ha

42 Así lo concibe el Vaticano II y PDV (Cf. MNA, 443-446).

43 PDV, cap. II.

44 A. Favale, El ministerio presbiteral. Aspectos doctrinales, pastorales y espirituales,

S. de E. Atenas, Madrid 1989, 74.258.

45 Ésta es la arquitectura de nuestro libro MNA. Primar una de las referencias a 
superado el endémico reduccionismo sacerdotal al mismo tiempo que su aislamiento. Éste es nuestro proyecto: el sacerdote en relación con la Trinidad, con Cristo, con la Iglesia, con el episcopado, con los fieles, con los demás sacerdotes, y ello armoniosa y simultáneamente. Creemos que este planteamiento del tema da cumplida respuesta a la altura de la Iglesia y de la teología de nuestros días, y, en definitiva, a la secular pregunta: ¿qué es el sacerdote? El sacerdocio nuevo y definitivo de Cristo se nos presenta hoy, actual y vigente en sus ministros, con un nuevo rostro, como don de Dios concedido graciosamente.

\subsection{Teología del presbiterio46}

La teología del presbiterio es un tema que está pidiendo una atención y desarrollo mucho mayor de lo que se le ha prestado hasta ahora. Le confiere actualidad y urgencia la eclesiología de comunión. El presbiterio es una realidad rica, que ofrece diversas vertientes: realidad teológico-sacramental, realidad vital-pastoral, realidad jurídico-organizativa 47 ; este triple rostro debería respetar el orden que se deduce de su diverso rango teológico y que es el que acabamos de enunciar.

El presbiterio es fruto del sacramento del orden, y es el organismo en el que se da la máxima comunión teológica entre los presbíteros, tanto entre sí como con el obispo, y no es parangonable con ningún otro tipo de asociación sacerdotal. Es, por ello, la primera y mejor realización de la fraternidad sacerdotal48, el mejor exponente que la encarna y expresa.

Ignacio de Antioquía sentó los primeros hitos teológicos del presbiterio o comunión fraternal de los ministros ${ }^{49}$. Todo sacerdote nace al sacerdocio como miembro del presbiterio, inserto por el sacramento en este organismo. Por tanto, el presbiterio como realidad teológico-sacramental precede al sacerdocio conferido al individuo; no es la suma de los presbíteros, sino una magnitud anterior a cada uno de ellos, al derecho a asociarse y a cualquier agrupación voluntariamente elegida. Puede decirse que el presbiterio no se

expensas de las otras, puede ser teológicamente legítimo pues se trata de una opción personal que hay que respetar, pero, en el fondo, distorsiona el tema e impide una visión completa y armoniosa. Es el caso de varias obras actuales, magníficas en sí, pero insuficientes por parciales e incompletas al no manifestar la riqueza del sacerdocio.

46 Cf. MNA, 386-389.

47 Cf. ICIM, 266-282.

48 Cf. Tertuliano, De exhort. cast. 7.

49 Ad Trall. 7. 
elige, se nace en él en cuanto presbítero. Obispo y presbíteros forman un solo presbiterio (PO 8a; LG 28b), una sola familia, cuyo padre es el obispo (CD 28a). El presbítero podrá vivir en soledad, pero no en solitario, sin relación al presbiterio. Éste es el soporte sobre el que se levantan las diversas formas que puede adoptar la fraternidad presbiteral.

El presbiterio, como organismo de comunión de los pastores de una Iglesia particular, obispo y presbíteros, debería ser la plataforma desde la que se organizara toda la acción ministerial diocesana. Los presbíteros son colaboradores y consejeros necesarios del obispo en el ministerio y oficio de enseñar, santificar y apacentar al pueblo de Dios (PO 7a), por tanto, el presbiterio como sujeto colectivo es el responsable de la Iglesia particular y de su misión.

El presbiterio es el mejor órgano de corresponsabilidad del ministerio ordenado, es la instancia que encarna y representa al ministerio ordenado y la expresión de la articulación entre los diversos grados el ministerio propio de una Iglesia-comunión. En una palabra, el presbiterio debería ser la instancia ministerial primera en la Iglesia particular. Los pasos dados en esta dirección son aún tímidos, pues el presbiterio no pasa de ser un organismo consultivo del obispo ${ }^{50}$. Un paso más se ha dado con el Colegio de Consultores, que tiene función deliberativa ${ }^{51}$. Es el presbiterio el que ofrece la matriz inmediata de la corresponsabilidad ministerial, pues en él echan sus raíces entre los sacerdotes los lazos de carácter teológico, espiritual, pastoral, humano y formativo 52 .

El presbiterio hace posible la vivencia del sacerdocio comunitariamente. Hay que dar paso del mero asociacionismo sacerdotal al presbiterio si se quiere asentar sobre bases teológicas la fraternidad y la misión presbiteral.

El presbiterio pone de manifiesto que existe un verdadero corpus, ordo53 o comunidad de ministros ordenados. El presbiterio se sitúa en la línea de la unidad, como ya señalaba Ignacio de Antioquía: un solo cáliz, un solo altar,

50 Cf. ICIM, 283-287.

51 Cf. Ibid., 281-282; Código de Derecho Canónico, cc. 501.502.

52 La unidad de vida y el sentido de su ministerio los presbíteros lo encontrarán únicamente en esa comunión afectiva con los obispos, de los cuales son colaboradores, y con los demás presbíteros por la unidad de un mismo presbiterio (Conferencia Episcopal Francesa, Ministerio y vida de los presbíteros diocesanos en Seminarios 112 (1989) 233); cf. S. Gamarra, La delicada y necesaria relación con el obispo. La coherencia en el presbiterio en Comisión Episcopal del Clero, Espiritualidad del presbítero diocesano secular. Simposio, EDICE, Madrid 1987, 684s.; J. Delicado Baeza, La relación del presbítero con el obispo en Comisión Episcopal del Clero, Ibid., 249-264.

53 Se es presbítero mediante la inserción en el 'orden' del presbiterio (PO 8a; Ireneo, Adv. haer. IV, 26.4) El término ordo deja vislumbrar el carácter colegial o coral del presbiterio. 
un solo obispo con el presbiterio54; ve al presbiterio tan estrechamente unido al obispo que, dirigiéndose en sus cartas a los fieles, les exhorta a que no hagan nada sin el obispo y el presbiterio, y a que reverencien y respeten al obispo y al presbiterio.

En resumen, recibir el sacramento del orden en modalidad presbiteral es ser recibido eucarísticamente en el seno del presbiterio diocesano. Ser presbitero es ser co-presbitero de una Iglesia particular55.

\subsection{Fraternidad sacramental}

La comprensión del presbítero en referencia a los demás presbíteros es una perspectiva relativamente nueva, casi nos atreveríamos a decir que no ha entrado todavía en el imaginario de los sacerdotes, y apenas se empieza a tener en cuenta en los tratados sobre el sacerdocio. La relación entre presbíteros se ha dado en la historia desde una vertiente más bien espiritual, pero ahora se plantea con intencionalidad y desde coordinadas teológicas. Hay una muy estrecha relación entre el tema del presbiterio abordado anteriormente y el de la fraternidad sacerdotal. Se pone de relieve ahora, por una parte, la dimensión colegial del presbiterado56, y, por otra, el origen sacramental de dicha fraternidad: Los presbíteros, constituidos por la ordenación en el sacramento del presbiterado, se unen entre sí por íntima fraternidad sacramental $(\mathrm{PO} 8 \mathrm{a})^{57}$. El presbítero se debe entender como co-presbitero (1 Pe 5, 1), de hecho, ya el Nuevo Testamento y la Iglesia más antigua no conocen sacerdotes particulares, sino presbiterio 58.

La fraternidad sacerdotal se debe plantear desde una perspectiva bíblico-eclesialteológica59, cuyos ejes fundamentales son la ordenación y la misión compartidas.

\section{Ad Philad. 4.}

55 L. Trujillo, Relaciones propias del presbítero y espiritualidad en Comisión Episcopal del Clero, Espiritualidad sacerdotal. Congreso, EDICE, Madrid 1899, 136.

56 Los presbiteros forman con el obispo un solo presbiterio (PO 8a; LG 28b; CD 28a) en virtud del sacramento compartido; la perspectiva de la fraternidad que aquí nace no es jurídica, ni siquiera pastoral, sino teológico-sacramental.

57 Se da aquí un salto cualitativo teológicamente: la fraternidad sacerdotal es fruto del sacramento. Anteriormente al concilio, se presentaba esta fraternidad desde la vertiente de la espiritualidad: íntima fraternidad (LG 28c), de la mutua ayuda o de la amistad.

58 K. Rahner, El obispo en la Iglesia en Escritos de Teología, VI, Taurus, Madrid 1969, 390.

59 Así se entendió en los comienzos. Puede darse también una justificación de tipo humano, operativo y pastoral, pero solo la fundamentación teológico-sacramental proporciona la solidez y seguridad que pone de manifiesto su necesidad y que alienta a su cultivo entre los sacerdotes. 
La fraternidad sacerdotal tiene rasgos propios, un perfil y peculiaridad específica, por lo que no debe pretender imitar la fraternidad de la vida religiosa. Las condiciones existenciales y pastorales del sacerdote diocesano son distintas de las del religioso y, sobre todo, es distinta la fundamentación teológica: el sacramento del orden y no el voto característico de la vida religiosa.

Se debe insistir en la fundamentación bíblica de esta fraternidad. En el Nuevo Testamento se nos presenta la vida apostólica que ha nacido en la escuela de la praxis de Jesús. ¿Cómo procedió Jesús con los que serán sus enviados y representantes? Veamos:

+ Jesús elige a los Doce como grupo: "Y los hizo Doce", dice el original griego (Mc 3,13.14), y los Doce pasa a ser el nombre del grupo, un sujeto colectivo;

+ Instruye al grupo de los íntimos con dedicación especial (Mc 13, 12.18-23.36-43; Lc 12, 12s.);

+ Encomienda su tarea al grupo constituido por él (Mc 6, 37);

+ Los envía no aisladamente, sino formando grupo (Lc 9, 1-2; 10, 1);

+ Promete al grupo su indefectible asistencia (Mc 16, 20; Mt 28, 30);

+ Hace del grupo su testigo (Lc 24, 48; Hech 1, 4.8);

+ El grupo es en general el que recibe el aliento del Señor (Jn 20, 22);

+ Por último, ora por la cohesión del grupo (Jn 17).

La trayectoria de Jesús es clara: no se dirige a cada uno en particular60, sino que su estilo y talante constante es la formación de un grupo o comunidad de testigos. De Jesús sale un ministerio colegial. Jesús forma y envía una fraternidad61. El grupo de los llamados representa y manifiesta como tal grupo al que lo eligió y envió. Así queda sancionada la representatividad corporativa que el grupo hace de su Señor.

Jesús llamó a los que quiso para construir la fraternidad entre los hombres (LG 1), siendo ellos fraternidad; se construye la comunidad con un instrumento comunitario; los agentes de comunidad deberán ser espejo y modelo de fraternidad. El sujeto evangelizador es comunitario ${ }^{62}$. El discipulado de Jesús crea una situación especial de fraternidad misionera, un modo característico de vivir y actuar que se traduce en el tipo de relación de los presbíteros entre sí y con el obispo.

60 Con la única excepción de Pedro en algún caso, pero aún entonces sin desligarle del grupo.

61 Este gesto evangélico ha quedado profundamente grabado en la memoria de la Iglesia (Cf. PO 10c)

62 Idea central en Pablo VI, Exh. apostólica Evangelii nuntiandi, y fuertemente reforzada en el Vaticano II. 
La fraternidad sacerdotal, además de la fundamentación bíblica deducida de la praxis de Jesús, cuenta con una fundamentación sacramental y eclesial. La verdadera fuente es indiscutiblemente cristológica, es el mismo Cristo el que une a los presbítero en esa fraternidad que nace del mismo y único sacerdocio y ministerio de Cristo (PO 10a), y que es además ministerio y misión apostólica (PO 2b), pero ello se actúa en el sacramento del orden, es fraternidad sacramental, y, por consiguiente, no es facultativa u optativa, sino necesaria y constitutiva del ministerio apostólico. El sacramento hace a los ordenados signos y testigos del Señor y los enrola en su misión de forma corresponsable.

La fraternidad sacerdotal es un punto básico de la teología del sacerdocio ministerial por su íntima vinculación con el sacramento del orden. El Vaticano II insiste en esta idea y con ello da un salto cualitativo tanto en el tema de la espiritualidad como en el del ministerio sacerdotal63. Es una fraternidad específica y se apoya en bases objetivas, en la gracia de la ordenación; es el lazo peculiar que une a los presbíteros y que no se tiene con el común de los fieles. No se trata de ser simplemente amigos, se trata de ser hermanos por un nuevo título, y el hermano no es elegido, sino que es recibido como don o regalo. Esta fraternidad se manifiesta con un expresivo gesto en el rito de la ordenación por la imposición de manos de los presbíteros asistentes, aunque no sean concelebrantes.

La ordenación y la misión compartidas crean en los sacerdotes una relación múltiple y nueva entre ellos ${ }^{64}$. Se nace al presbiterado con el sello de la fraternidad que otorga el sacramento; ya no se puede actuar por libre y de forma autónoma, por lo que operativamente debe reinar entre los sacerdotes el espíritu fraterno (PO 8c) y la más omnímoda cooperación (PO 8a)65.

63 Aunque se entreguen a diversos intereses, ejercen un solo ministerio sacerdotal a favor de los hombres. Todos los presbiteros son enviados para cooperar a la misma obra. Todos conspiran ciertamente a un mismo fin (PO 8a).

64 Cada uno está unido con los restantes miembros de esta agrupación sacerdotal por especiales lazos de caridad apostólica, ministerio y fraternidad (PO 8a).

65 El magisterio de nuestros días lo ha expresado de forma enérgica: Ningún presbítero puede cumplir cabalmente su misión aislado y como por su cuenta, sino solo uniendo sus fuerzas con otros presbíteros, bajo la dirección de los que están al frente de la lglesia (PO 7c) Todos y cada uno de los presbíteros están unidos con sus hermanos por el vínculo de la caridad, de la oración y de la omnímoda cooperación, y así se pone de manifiesto aquella unidad con que Cristo quiso fueran los suyos consumados en uno, para que conociera el mundo que él había sido enviado por el Padre (PO 8a). PDV sienta lapidariamente el principio: El ministerio ordenado tiene una radical forma comunitaria y puede ser ejercido solo como una tarea colectiva (N. 17a). 
La peculiar fraternidad de los sacerdotes nace de raíz sacramental y afecta a todas las fibras de la existencia ministerial, expresándose mediante el compartir dones y bienes, proyectos e ilusiones, lo que se es, se hace, se vale y se tiene. De esta forma, se da cuerpo y se visualiza la fraternidad.

De esta fraternidad se deriva la corresponsabilidad pastoral, se hace una fraternidad apostólica, o sea, la solidaridad en el trabajo apostólico de los que son solidarios en la ordenación y en la misión. El trabajo colegial66 es el propio de una fraternidad $y$, al mismo tiempo, es símbolo del ser mismo de la Iglesia que los envía y a la que representan, una Iglesia-comunión expresada en un ministerio con carácter fraternal, comunitario, colegial. Se ha establecido entre los presbíteros un lazo especial que el Vaticano II denomina caridad apostólica (PO 8a). La fraternidad presbiteral, por tanto, se ilumina también teológicamente desde la misión apostólica compartida e íntimamente ligada a la ordenación ${ }^{67}$. La obra, el fin y los intereses de los presbíteros son comunes. Los aúna el Señor que llama, el sacramento que comparten, la misión a la que se les destina, la Iglesia dentro de la cual viven y actúan. La fraternidad presbiteral debe traducirse operativamente en el ejercicio comunitario y en la corresponsabilidad vivida y claramente expresada. El ministerio sacerdotal no se ha hecho para solitarios.

\subsection{Espiritualidad propia y específica68}

\subsubsection{La espiritualidad como elemento teológico: identidad y espiritualidad sacerdotal}

La espiritualidad sacerdotal se ha ganado un puesto en el marco de la teología del sacerdocio y en los planes académicos de los centros de formación, superando los tiempos en los que se la consideraba extrarradio o como un apéndice de la teología del sacerdocio, y pasando a ser un capítulo de la misma. Es frecuente encontrar en las publicaciones de los últimos años títulos como Teología y espiritualidad del sacerdote y similares. Se contaba con una muy abundante literatura espiritual y ascética sobre el sacerdocio y una

66 Véase texto de PDV en Nota anterior.

67 Aunque se entreguen a diversos menesteres, ejercen un solo ministerio sacerdotal a favor de los hombres. Todos los presbiteros son enviados para cooperar a la misma obra. Todos conspiran ciertamente a un mismo fin (PO 8a).

68 Cf. Comisión Episcopal del Clero, Espiritualidad del presbítero diocesano secular. Simposio, EDICE, Madrid 1987; Id., Espiritualidad sacerdotal y ministerio. Documento de trabajo, EDICE, Madrid 1988; Id., Espiritualidad sacerdotal. Congreso, EDICE, Madrid 1989; R. Sánchez Chamoso, MNA, 455-527; M. Caprioli, La espiritualidad sacerdotal. Líneas fundamentales, Madrid 2007; S. Gamarra, Manual de espiritualidad sacerdotal, Burgos 2008. 
reiterada exhortación a la santidad, pero con una teología endeble en su base. La teología no considera ahora a la espiritualidad como algo periférico a su quehacer o como mero corolario piadoso; se trabaja por una auténtica teología espiritual del sacerdote. El aporte del Vaticano II ha sido decisivo para el cambio69.

Nos referimos aquí a una espiritualidad propia y especifica del sacerdote, con fuentes, modalidad y características peculiares que correspondan al ministerio y a la vida sacerdotal, y que se diferencia de otras espiritualidades. Se trata de superar una larga tradición en la que la espiritualidad del sacerdote se presentaba como una imitación, copia o herencia en préstamo de la espiritualidad de los estados de perfección o la aristocracia espiritual encarnada en la vida religiosa; ante ésta, el sacerdote era víctima de una especie de complejo de inferioridad 70 . En la actualidad, planteamos el tema sin nostalgia ni añoranza de ese largo pasado, sino buscando una espiritualidad a la medida del sacerdote, $\mathrm{O}$, con palabras del concilio, conseguir la santidad de manera propia (PO 13a).

Hay una estrecha relación entre identidad y espiritualidad del sacerdote, por lo que la espiritualidad gana en solidez y en densidad teológica y, al mismo tiempo, contribuye a enriquecer la teología del sacerdocio. La espiritualidad sacerdotal es la vida según el Espíritu que se nos ha dado (Gál 4, 6; Rom 8, 15 ; Mc 14, 36) y el estilo de vida configurado por la propia identidad sacerdotal. Este planteamiento es de la máxima importancia: identidad y espiritualidad sacerdotal discurren al unísono, corren una misma suerte y son teológicamente indisociables.

El Espíritu nos anima en cada caso según la vocación a que hemos sido llamados (Ef 4,1$)$. No hay espiritualidad cristiana al margen de la propia vocación y del carisma recibido por cada uno. Cada uno debe caminar sin vacilación por el camino de la fe viva según los dones y funciones que le son propios (LG 41a). Por consiguiente, la identidad (vocación) propia del monje, del religioso, del laico o del sacerdote pide y justifica una espiritualidad propia y específica. En el caso del sacerdote, la gracia fontal de vida espiritual es la propia del sacramento del orden como lo vio sagazmente el Vaticano II (PO 14), una gracia nueva y distinta de la del bautismo ${ }^{71}$. Por eso, podemos hablar de espiritualidad presbiteral como forma específica de vida según el

69 Sobre la perspectiva abierta por el concilio Vaticano II y siguiendo sus huellas, cf. Código de Derecho Canónico, cc. 273-287.

70 Un dato bastaría para sobrepasar este estado de ánimo: la espiritualidad del sacerdote se asienta y nace del sacramento del orden mientras que la del religioso se basa en el voto. La diferencia teológica entre un caso y el otro es patente.

71 Cf. DS 1766. 
Espiritu y como una modalidad de la perfección de la caridad.

Las bases de la peculiar espiritualidad del sacerdote son el nuevo sacramento que ha recibido y la función especial que se le confía en la Iglesia, o sea, sacramento y ministerio. La ordenación es un acontecimiento de gracia, una nueva modalidad de presencia y acción del Espíritu en el sujeto ordenado, una gracia que incorpora al sujeto al ministerio apostólico y de salvación, haciéndole instrumento vivo de Cristo sacerdote, cabeza, pastor y esposo de la Iglesia. El don del Espíritu conferido en la ordenación se convierte en fuente de renovación interior, que asume la totalidad del ser del presbítero y le habilita para obrar in persona Christi e in nomine Ecclesiae.

\subsubsection{Peculiaridad de la espiritualidad sacerdotal: 'en el ejercicio del ministerio'}

Pero el dato más rico y novedoso aportado por el concilio Vaticano II es cifrar la espiritualidad sacerdotal en el ejercicio del ministerio: Los presbíteros conseguirán de manera propia la santidad ejerciendo sincera e incansablemente sus ministerios en el Espíritu de Cristo (PO 13a)72. La insistencia del Vaticano II en esta línea es monocorde. El giro operado es profundo: de la consideración de la acción ministerial como obstáculo o como banco de prueba para la vida espiritual porque absorbe y desgasta a su consideración como alimento y estímulo73. El sacerdote no logra la santidad a pesar de el ministerio, ni solo con ocasión de el ministerio, sino mediante o en el ejercicio del mismo ministerio. Se da una circularidad entre espiritualidad y ministerio: imitamini quod tractatis (PO 13c). Una solución lúcida y realista, que ofrece salida a un problema enconado para muchos sacerdotes: conjugar acción y oración. Se presentan inseparables la objetividad sacramental del ministerio y la subjetividad existencial del ministro.

En el ministerio de anunciar la palabra, en las acciones litúrgico-sacramentales y en el pastoreo del pueblo de Dios alcanzará el presbítero la cumbre de la santidad y crecerá en su ser sacerdotal74. Ministerio y espiritualidad se

72 A continuación, el concilio despliega las funciones de ministro de la palabra, del culto y de guía del pueblo de Dios, de las que se ha ocupado PO 4, 5 y 6 , y que glosa PDV, n. 26.

73 Las preocupaciones apostólicas, los peligros y contratiempos no solo no son obstáculo, antes bien, los presbíteros ascienden por ellos a una más alta santidad (LG 41c), hasta el punto de poder decir que el máximo vigor de la vida espiritual ha de provenir de la propia actividad pastoral (OT 9b).

74 El ejercicio intenso del ministerio va convirtiendo en existencialmente presbítero a aquel que lo es sacramentalmente por la ordenación (Comisión Episcopal del Clero, Espiritualidad sacerdotal y ministerio. Doc. de Trabajo, EDICE, Madrid 1988, 84). 
hallan imbricados de forma singular, la espiritualidad depende intrínsecamente del ministerio. Reforzar la espiritualidad lleva al equilibrio entre lo que pensamos, lo que queremos ser y lo que hacemos; la espiritualidad pone a punto el instrumento pastoral del ministerio sacerdotal.

Como resultado de este planteamiento, se derivan importantes consecuencias. Quizá la más importante sea la unidad y armonía de la existencia del sacerdote, certeramente señalada por el Vaticano $\|^{75}$, que se ve sometido, cuando no es víctima, de una peligrosa dicotomía entre la tarea, por una parte, y, por otra, el cultivo de su vida espiritual. Otra consecuencia es el perfil que ofrece del sacerdote, que es hombre de oración, no hombre de rezos.

Otro sugestivo capítulo abierto por el Vaticano II ha sido el de la caridad pastora ${ }^{6} 6$. Equivalentes pueden ser la caridad apostólica (PO 8a) y el carisma pastoral $(2 \mathrm{Tim} 1,6)$. La caridad pastoral es sencillamente el amor propio del pastor 77 . La espiritualidad del sacerdote es una espiritualidad pastoral, cuya alma es la caridad pastoral, expresada sobre todo en la figura del buen Pastor.

Podemos decir que la espiritualidad presbiteral bebe del propio pozo (Prov 5 , $15)$ al hacerla pivotar sobre el sacramento del orden y alimentarla en el ejercicio del ministerio. No es imitación de ninguna otra espiritualidad. Arranca de premisas teológicas propias y debe ser entendida y vivida de acuerdo con las exigencias de la consagración y la misión sacerdotal. La identidad del presbítero confiere carácter propio a su espiritualidad. El sacramento del orden reelabora la identidad cristiana debida al bautismo. La caridad pastoral expresa la identidad del presbítero en la vertiente operativa o apostólica. Por otra parte, la caridad pastoral es, en el ámbito de las múltiples tareas sacerdotales que amenazan con la dispersión, el vínculo de la perfección sacerdotal (PO 14b) y de todas las virtudes para usar la conocida idea paulina. En efecto, la caridad pastoral impregna y matiza todo en el sacerdote, por lo que las virtudes cristianas como los consejos evangélicos son encarnados por el sacerdote con perfil propio ${ }^{78}$. Todo esto tiene una versión

75 En cuanto a los presbíteros, envueltos y distraídos en las muchísimas obligaciones de su ministerio, no sin ansiedad buscan cómo puedan reducir a unidad su vida interior con el tráfago de la acción externa (PO 14a).

76 Es uno de los conceptos más logrado del concilio, recuperando una vieja idea patrística: PO 14; 15b; 16a, y PDV que hace de la caridad pastoral el concepto-estrella del documento.

77 Amoris officium (Agustín): PDV 11c.

78 Sugerente perspectiva que espera el desarrollo que se merece: Cf. PO 15.16.17; PDV, nn. 28.29.30; un desarrollo inicial en MNA, 484-523. Capítulo importante de la espiritualidad presbiteral renovada. 
sacerdotal, o sea, estilo y matiz propios correspondiente al perfil espiritual del pastor. Las exigencias comunes a todos los cristianos no implican uniformidad en el modo de vivirlas, sino que se plasmarán de acuerdo con la vocación personal y la función de cada uno en la Iglesia y en la sociedad. La gracia del sacramento del orden confiere un carácter específico y original a las virtudes ${ }^{79}$ y a los consejos evangélicos ${ }^{80}$ en el caso del sacerdote. Virtudes y consejos quedan impregnadas por el ministerio y reciben un especial colorido en la existencia sacerdotal.

Debemos dejar constancia de que la vida espiritual del presbítero no se agota en el ejercicio del ministerio. El organismo sobrenatural, creado por la gracia bautismal y por la gracia de la ordenación, incluye las prácticas comunes a todos los cristianos (PO 18), y, de modo especial, incluye las virtudes teologales y morales, así como los dones del Espíritu Santo, presentes y operantes. Otro punto que debe quedar claro es que el sacerdote, como todo cristiano, necesita de tiempos especiales de oración y no puede confiar su espiritualidad solo al ejercicio del ministerio. Éste será más auténtico en la medida en que la vida espiritual sea más viva ${ }^{81}$, hay circularidad entre santidad personal y ejercicio del ministerio.

\subsubsection{La peculiar ascesis sacerdotal}

Para cerrar este capítulo sobre la espiritualidad sacerdotal vamos a fijarnos en un aspecto entre muchos otros de todos conocidos: la ascesis peculiar que comporta la vocación sacerdotal y el ministerio hoy82. El sacerdote sabe que viene de Dios, pero que es para el pueblo83; éste es la niña de los ojos

\section{Cf. MNA, 484-491.505-527.}

80 Tras la huella del concilio, PDV glosa y desarrolla ampliamente lo aportado por el Vaticano II sobre los consejos evangélicos en su versión sacerdotal (Nn. 28.29.30), a partir del radicalismo evangélico y de la caridad pastoral (PDV, n, 27).

81 La santidad misma de los presbiteros contribuye en gran manera al ejercicio fructuoso del propio ministerio (PO 12c).

82 Cf. MNA, 564-568. En la preparación del Sínodo de 1992, se dijo que es el grupo eclesial que más ha sufrido después del concilio, en una larga travesía del desierto.

83 Cf. R. Sánchez Chamoso, Ministerio sacerdotal: Desde Cristo, en la Iglesia, para la comunidad en ITER 41 (2006) 71-94; en Aparecida se recuerda que el Vaticano II establece el sacerdocio ministerial al servicio del sacerdocio común de los fieles, una idea que se repite cada con más intensidad desde el Vaticano II, aunque, a su modo, se había dicho en la mejor tradición sacerdotal: El sacerdote es más de los otros que de sí. Jesucristo le ha escogido para esto. Hay profesiones sociales, v. gr. abogado, médico, pero lo son para sí también. El sacerdote, no; es el hombre de la caridad (Beato Manuel Domingo y Sol). 
de Dios (Dt 32, 10; Sal 16, 8), desde el principio Dios cuida de su pueblo con infatigable ternura ${ }^{84}$. Y esto la sabe el sacerdote. El pueblo es más importante que los que le son enviados; el pueblo es la razón de ser del sacerdote, pues ha sido puesto para apacentar al pueblo de Dios (LG 18a). Más aún, el pueblo es el fin querido por Dios y el sacerdote el medio que Dios ha arbitrado para alcanzar ese fin85. El núcleo de la ascesis que conlleva el sacerdocio ministerial queda expresado en aquellos términos evangélicos: Conviene que él crezca y yo disminuya ( $\mathrm{Jn} 3,30)$, es decir, debe crecer la comunidad a costa de la vida del sacerdote. La entrega que se pide al sacerdote es total, es una verdadera expropiación, la suya es una proexistencia. Incluso cuando preside como jefe y responsable de la comunidad, debe ejercer esa presidencia como un servicio (Eclo, 32,1$)^{86}$. Las palabras más duras de la Biblia están dirigidas a los pastores que no sirven a las ovejas, sino a sí mismos. La advertencia es categórica: $A$ los que están arriba se les hará un severo juicio (Sab 6, 5; cf. 1 Pe 4, 17; Sant 3, 1; Jer 25, 29; 1 Cor 11, 13...).

\subsection{En la paradoja cristiana de la mediación}

\subsubsection{Cristo, único mediador}

El ministerio sacerdotal se inscribe en la economía de las mediaciones, pero se trata de una mediación tan peculiar que es necesario explicarla para deshacer un malentendido muy difundido.

En primer lugar, el único sacerdote, Cristo, es también el único mediador (Heb 9, 15; 12,24; 1 Tim 2, 5) Frente a la pluralidad de mediadores en el sacerdocio levítico ${ }^{87}$, ninguno de los cuales realizaba el sacerdocio agrada-

84 Tú serás el pastor de mi pueblo (2 Sam 5, 2); apacienten el rebaño que Dios les ha confiado (1 $\mathrm{Pe}, 5,2)$.

85 Cf. PDV, nn. 14a; 16b; 17d; 76e... Llama la atención la insistencia de esta idea hoy tanto en el magisterio como en la teología.

86 Pablo nos habla de presidir con solicitud (Rom 12, 8) No se trata de quererse presentar como uno más del pueblo porque no es verdad, sino atenerse a la célebre expresión que acuñó la tradición cristiana: praeesse ut prodesse, en cristiano: presidir es servir. Oportet prodesse magis quam praeesse (San Benito, Regla 64.8). Y san Bernardo escribe a su antiguo alumno y ahora papa Eugenio III: praesis ut prosis (De cons. III, 1, 2).

Por ser prolongación de la presencia de Cristo, único y supremo Pastor, siguiendo su estilo de vida y siendo como una transparencia suya en medio del rebaño (PDV, $\mathrm{n}$. 15), se le exige unas funciones peculiares que no están encomendadas a los demás, entre otras, ser signo de Cristo mediante su re-presentación en la presidencia de la comunidad.

87 Los otros sacerdotes fueron muchos, porque la muerte les impedía perdurar, éste, 
ble a Dios, irrumpe el mediador único. Pero hay más, y es que ahora se trata de una mediación del todo peculiar. En efecto, hay que superar el modo humano y ordinario de concebir la mediación, que podemos representar por un triángulo y que descansa sobre tres elementos: el emisor, el destinatario y el medio por el cual llega lo emitido al destinatario. Éste era el caso del Antiguo Testamento y de las religiones: Dios, mediante el ministro-mediador, alcanza al hombre en su salvación. El mediador sirve de puente y salva la distancia entre Dios y el hombre. Es el mediador sagrado, clásico en las religiones.

No es éste nuestro caso. Ahora, entre Dios y el hombre no hay un tercero con el oficio de mediador, sino que el mismo Dios llega al hombre y viceversa, Dios se comunica con el hombre inmediatamente por cuanto el mediadorJesús es Dios.

Debemos continuar especificando el tipo de mediación. ¿Cómo ejerce ahora Cristo glorificado su sacerdocio único? No por estructuras mediadoras creadas por el hombre, ni por mediadores sagrados, sino por una inmediatez mediada, en una mediación para la presencia inmediata, pues en los ministros el que actúa es el Señor, los ministros son manifestación visible de la mediación sacerdotal de Cristo. Al ministro le constituye una representación sacramental, es instrumento vivo del mediador Cristo88.

Por tanto, en la fórmula inmediatez mediada no hay contradicción, ni incompatibilidad de términos, sino la paradoja del misterio. En efecto, hay inmediatez por cuanto Cristo sigue siendo y actuando como sacerdote, y es mediada porque ejerce su sacerdocio en el ministerio sacerdotal. Es Cristo Sacerdote quien actúa en los sacerdotes de Jesucristo, se encarna sacramentalmente en su ministro. El ministro ordenado no sustituye, reemplaza o sucede la mediación de Cristo Sacerdote, sino que es Cristo quien le asume a él para ejercer sacramentalmente su sacerdocio a lo largo de la historia. Lo que Cristo hizo históricamente lo continúa haciendo ahora sacramentalmente en el ministerio de sus sacerdotes; es la misma acción, pero realizada de forma diversa; no se repite la acción de Cristo, sino que se actualiza y prolonga en la historia sacramentalmente. Pues Cristo Sacerdote ni ha abdicado, ni ha desaparecido, ni ha delegado en otro que le sustituye, suple o reemplaza, sino que está siempre vivo para interceder por nosotros (Heb $8,1 ; 9,24 ; 10,11.21)$, de forma permanente 89 . La acción del sacerdocio ministerial es acción de Cristo Sacerdote, pues es éste quien actúa en sus

en cambio, como permanece para siempre, posee un sacerdocio que no pasará (Heb 7, 23-24).

${ }^{88} \mathrm{Cf}$. A. Vanhoye, Sacerdotes antiguos, sacerdote nuevo según el Nuevo Testamento, Sígueme, Salamanca 1984.

89 PDV, n. 5e. 
ministros; éstos actúan in persona Christi, representan a Cristo y le hacen presente, siendo su signo y sacramento ante la comunidad y para la comunidad. El sacerdote actúa como sacramento de Cristo Cabeza90.

Todavía podemos seguir preguntándonos: ¿por qué mediaciones? Si tenemos libre acceso a Dios (Ef 2, 18; Heb 10, 19; 12, 7; Lc 23, 45), ¿para qué los mediadores?, en último término, ¿no basta la mediación de Cristo, el único Mediador?

Veamos los principios. La comunidad primitiva tiene dirigentes (Heb 13, 7.17), jefes y responsables que la presiden y guían, no es una comunidad acéfala en la que todos tiene el mismo cometido. Esto no era visto como un atentado a la mediación única de Cristo. Más aún, es algo querido por Cristo. Textos básicos como Mc 3, 13-14 nos hablan de que el Jesús histórico llamó a algunos de entre sus seguidores, los asoció de forma especial a su obra y a su destino, los envió y encomendó la predicación del Evangelio y el servicio a los demás. No estoy hablando de todos ustedes; ya sé bien a quiénes elegí (Jn 13, 18; cf. 15, 16); como el Padre me envió, yo también los envío a ustedes (Jn 20, 21; cf. 17, 18). Al enviarlos, les comunicó su exousia (Mt 28, 18; cf. 11,27$)^{91}$ para actuar ministerialmente en su nombre. En una palabra, algunos reciben y continúan la obra de Cristo por voluntad expresa del mismo 92. Por otra parte, el mismo Jesús invita a que se ruegue al Padre para que envíe obreros a su campo (Mt 9, 38) El que envía se identifica con los enviados, no hay competencia entre uno y otros ${ }^{93}$.

\subsubsection{El hombre necesita mediadores}

El hombre necesita acceder de algún modo y según sus posibilidades a Cristo Sacerdote, presente y actuante aquí y ahora. En este marco se inscribe el sacerdocio ministerial. Éste ostenta la representación peculiar de Cristo Cabeza, Pastor

90 J. M. R. Tillard, La Iglesia local, Sígueme, Salamanca 1999, 169. La misma argumentación, salvadas las distancias, vale para la fórmula 'in nomine Ecclesiae'. Las acciones de los ministros son eclesiales, no puramente personales, pues el sacerdocio ministerial ostenta una re-presentación eclesial significativa; es la lglesia la que actúa en los 'ministros de la Iglesia'.

91 EI Vaticano II usa las expresiones potestad sagrada (PO 2b), potestad espiritual (PO 6a).

92 Es significativo el entrenamiento a que somete Jesús a sus discípulos al enviarlos mientras él vivía todavía con ellos: Jesús designó a otros setenta y dos y los envió por delante de dos en dos (Lc 10, 1; cf. Lc 9, 12; Mc 6, 7), cumpliendo la promesa que les había hecho (Mc 3, 14).

93 Les aseguro que todo el que recibe a quien yo envíe, me recibe a mi mismo y, al recibirme a mi, recibe al que me envió (Jn 13, 20; cf. Mt 10, 40). Quien los escucha a ustedes, a mi me escucha (Lc 10, 16). Yo estoy en mi Padre, ustedes en mi y yo en ustedes (Jn 14, 20). 
y Esposo de la Iglesia, y esto lo especifica y le confiere un papel representativo peculiar ante la comunidad. Se debe insistir en esta idea. El pueblo de Dios necesita signos: pastores, guías y representantes del Señor elegidos por él. Es la comunidad la que necesita ministros que medien, visibilicen y actúen la salvación (instrumentos vivos, dice el concilio), la obra del Señor glorificado inaccesible ahora a nuestros sentidos, y todo ello para el perfeccionamiento de los fieles, para la edificación del Cuerpo de Cristo (Ef 4, 13)94.

En la economía de la salvación es la comunidad la que necesita ministros, no es Dios quien necesita mediadores; Dios se adapta a la comunidad (condescendencia divina) con la institución de ministros que presidan, lideren, sirvan, pastoreen al pueblo; el hombre, la comunidad necesitan medios adecuados a su modo de conocer que hagan presente, comprensible y visible el sacerdocio de Cristo, y para ello Dios ha instituido un signo ${ }^{95}$.

Por tanto, no se ve incompatible el único Mediador y la mediación apostólica que él mismo instituyó, y que no menoscaba la mediación de Cristo. La comunidad primera vivió esta experiencia y dio este paso sin traumas, y tanto las Cartas Pastorales como la Primera Carta de Pedro y la Carta de Santiago hablan del ministerio de obispos-presbíteros al frente de la comunidad. El punto teológico decisivo no es el hecho de la mediación, sino el tipo del todo peculiar de mediación que expusimos anteriormente.

\subsection{Desde Cristo, en la Iglesia, para la comunidad}

Abordamos tres puntos por igual constitutivos del sacerdocio ministerial. La historia nos muestra que es fácil caer en planteamientos reductivos, enfatizando alguna de las caras del sacerdocio y dejando en la penumbra otras. Es, por tanto, importante resaltar lo realmente constitutivo del ministerio sacerdotal y, por otra parte, guardar un equilibrio entre los componentes fundamentales del mismo.

El sacerdocio ministerial es una realidad compleja, lo que significa que entraña una gran riqueza. Su ontología o ser propio es de carácter relacional y, por

\footnotetext{
${ }^{94}$ Así lo reconoce el magisterio: Faltando la presencia y acción del ministerio, que se recibe por la imposición de manos acompañada de la oración, la Iglesia no puede estar plenamente segura de su fidelidad y de su visible continuidad. La comunidad cristiana no puede cumplir plenamente su misión sin el sacerdocio ministerial (Sínodo de los Obispos de 1971, El sacerdocio ministerial, Sígueme, Salamanca 1972).

La acción pastoral del sacerdote no es una acción cualquiera, sino una acción cualificada y penetrada por el sacramento: cf. A. Vanhoye, Sacramentalidad del ministerio en Comisión Episcopal del Clero, Espiritualidad sacerdotal. Congreso, EDICE, Madrid 1989, 81s.

95 De ahí la importancia de lo expuesto sobre el sacerdote como signo sacramental, como representación, trasparencia y personificación de Cristo Sacerdote.
} 
tanto, depende de otras realidades teológicas que le confieren sentido, siendo las tres fundamentales Cristo, la Iglesia y el pueblo96. El sacerdote es esencialmente relativo a Cristo del que procede como de su fuente, a la Iglesia en la que actúa como en su medio o enclave histórico, a la comunidad en función de la que existe. En esta triple relación radica precisamente su novedad y originalidad. Este esquema cristológico-eclesiológico-comunitario supera, y no solo mejora, definitivamente el sacerdocio aarónico-levítico y todo otro sacerdocio de las religiones para inaugurar el sacerdocio definitivo, pues ya no habrá nuevas propuestas sacerdotales. El testimonio de la Escritura es categórico expresado en diversos registros (Heb 7, 11.15.18.19.22.27; 8, 6; 9, 11.1415.25; 10, 7.9.10.14.20...), y la Iglesia se reafirma en ello con términos bien explícitos ${ }^{97}$.

Con este planteamiento de red de relaciones de la teología del sacerdocio, a zaga de la doctrina del Vaticano II, se está superando el espléndido aislamiento98 en que había caído dicha teología, y, sobre todo, al asumir simultáneamente las vertientes cristológico-eclesiológico-comunitaria, se ha superado el peligro de reduccionismo, de ayer y de hoy, que enfatiza una de las dimensiones a expensas de las otras. Podemos afirmar que es ésta una plataforma ampliamente compartida en los años postconciliares, con lo que se ha sentado una sólida base para responder hoy a la pregunta: ¿qué es el sacerdote? Cristo (sacerdotes de Jesucristo), Iglesia (ministro de la Iglesia) y comunidad (pastor del pueblo de Dios) son referencias configuradoras de la ontología sacerdota/99.

96 R. Sánchez Chamoso, Ministerio sacerdotal: Desde Cristo, en la Iglesia, para la comunidad en ITER 41 (2006) 71-94; cf. PDV, n. 16.

97 Jesús refleja en si mismo el rostro perfecto y definitivo del sacerdocio de la nueva alianza (PDV, n. 13a) y, por tanto, el rostro definitivo del presbitero (Ibid., n. 5e). Cf. la sintonía de posturas teológicas al respecto: Conferencia Episcopal Alemana, El ministerio sacerdotal. Estudio bíblico-dogmático, Sígueme, Salamanca 1971, n. 16; Commission Internationale de Théologie, Le ministére sacerdotal. Rapport, Cerf, Paris 1971, Proposition 2; J. Guht, Alianza en L. Coeenen-E. Beyreuther-H. Bietelhard (dirs), Diccionario Teológico del Nuevo Testamento, I, Sígueme, Salamanca 1980, 88): A. Vanhoye, Sacerdotes antiguos, sacerdote nuevo según el Nuevo Testamento, Sígueme, Salamanca 1984, 197.221.

98 Cf. MNA, 252-254.

99 Tengamos presente un dato teológico importante: las tres referencias nacen del sacramento del orden: cf. MNA, 115-193; 195-225; 279-371 respectivamente.

Con todo, hay que hacer alguna precisión: en el caso de Cristo, la referencia se hace bajo la categoría de fuente o raíz; en el caso de la Iglesia, bajo la categoría de ubicación en la historia; se pasa a otro nivel: se mantiene la prioridad ontológica y 
Una palabra sobre el enclave eclesiológico del ministerio. Jesús no dejó un preciso esquema ministerial al que atenernos en el futuro. Lo que sí dejó fue a su Iglesia dotada con el don por antonomasia del Espíritu Santo que la presidiera y guiara en la historia. Se explica así la singladura histórica del ministerio en la Iglesia y bajo el impulso del Espíritu Santo. Se toman decisiones que no habían sido establecidas expresamente por Jesús; es el Espíritu el que suscita ministerios en la comunidad, en interacción constante con las coordenadas histórico-culturales 100 . Todo queda a la decisión de la Iglesia: Hemos decidido el Espíritu Santo y nosotros... (Hech 15, 25.28). La Iglesia es memoria y es actualización del Señor, en ella se encuentra y actúa el Señor. Cristo vive en su Iglesia, y opera singularmente por medio de sus ministros ${ }^{101 .}$

\section{PROBLEMÁTICA PENDIENTE}

El ministerio, superada la reducción clerical para entenderlo, se nos presenta como una realidad en evolución, algo dinámico, histórico, in fieri, por lo que conoce y tiene una historia, un desarrollo.

Desde otra perspectiva, el ministerio es funcional, pues nace para ser una diakonía efectiva, es esencialmente relativo a la misión (1 Cor 12, 7; Ef 4, 11-12), es la Iglesia operativamente considerada.

Ha sido posible conjugar en la historia fidelidad a las fuentes y creatividad de diversas formas de ministerio. La Iglesia no se ha sentido atada inmovilísticamente a las formas del pasado; lo ciertamente inamovible ha sido la misión que la Iglesia ha recibido y su responsabilidad en arbitrar los medios para llevarla a cabo. Debemos volver la vista a la comunidad primitiva, pluriforme ministerialmente, abierta a una evolución sin traumas ni complejo de infidelidad, rebasando todo fixismo o inmovilismo. Se adoptan formas plurales de ministerio y se hacen nuevos planteamientos a tenor del colorido de situaciones locales diferentes. No olvidemos que se ha dado un ser ministerial primigenio diversificado.

cronológica del sacerdocio de Cristo, como matiza oportunamente PDV: Jesús reflejó el rostro perfecto y definitivo del sacerdocio de la nueva alianza (n. 13a), en cambio, la referencia a la Iglesia es necesaria, aunque no prioritaria (n. 12d). Por último, la referencia a la comunidad es la última en la ejecución, pero la primera en la intención, pues para esto se inicia el proceso por voluntad de Dios.

100 Para una panorámica general sobre el itinerario del ministerio, cf. A. Lemaire, Les ministéres

101 Sínodo de los Obispos de 1971, El sacerdocio ministerial. Documentos, Sígueme, Salamanca 1972. Introducción 7. 
Hoy se nos ofrece un panorama inédito que presentamos con palabras de los obispos latinoamericanos: ¿Cuáles son los nuevos caminos ministeriales que se abren? ¿Cómo deben ser convenientemente promovidos? ¿En qué campos apostólicos deben situarse los nuevos ministerios? ¿Cómo pueden los actuales ministros de la Iglesia empeñarse en la reestructuración ministerial de la Iglesia?102 Muchas e incisivas preguntas que evidencian que nos hallamos ante un tema candente, esbozando un programa ministerial de cara al futuro. Sírvanos este testimonio como antesala de la revista que vamos a pasar de forma sucinta a algunos puntos de la teología del sacerdocio que reclaman un mayor desarrollo.

\subsection{Presbiterio}

La teología del presbiterio arranca del siglo II con Ignacio de Antioquía y, sin embargo, está en buena parte por asimilarse. Se han dado importantes pasos en el terreno jurídico-organizativo e incluso en el pastoral, pero en el plano teológico estamos apenas en los comienzos. Si preguntamos hoy al sacerdote sobre el presbiterio es muy poco lo que nos puede decir. No obstante, quizá tenemos en la teología del presbiterio una de las claves para una adecuada teología del presbiterado. El tiempo y la teología tienen la palabra.

El Vaticano II ha dado un decidido respaldo a la fundamentación teológica del presbiterio. Éste es, ante todo, fruto el sacramento del orden, es una fraternidad sacramental (PO 8a). Este organismo está formado por el obispo (como cabeza) y los presbíteros diocesanos y religiosos (como miembros) en una Iglesia particular; el presbiterio es el espacio teológico donde todos ellos se encuentran necesariamente.

De la teología del presbiterio cabe esperar un ministerio sacerdotal más solidario, una realización más fácil de la llamada pastoral de conjunto y una mejor expresión de la naturaleza comunional de la Iglesia, si tenemos en cuenta que el ministerio es la Iglesia en acción, la vertiente activa de la Iglesia.

Una sólida teología del presbiterio, profundizada teológicamente y hondamente asumida, incide directamente en la existencia del sacerdote y, por otra parte, en la organización y marcha de la Iglesia particular. En efecto, los presbíteros son presentados repetidamente por el Vaticano II como colaboradores del obispo, pero se trata de una colaboración que hay que pro-

102 Secretariado General del CELAM, Ministerios eclesiales en América Latina. Reflexión teológico-pastoral. Documento de síntesis (Encuentro sobre Teología y Pastoral de los Ministerios, celebrado en Cumbayá (Quito), 16-24 de agosto de 1974). Se puede encontrar en Seminarios 23 (1977) 265-266. 
fundizar tras las pistas del concilio103. En un pasaje importante del concilio, hablando de la obediencia que los presbíteros deben al obispo, se matiza diciendo que es una obediencia sacerdotal penetrada de espíritu de cooperación (PO 7b), colaboración con el obispo en el ministerio y oficio de enseñar, santificar y apacentar al pueblo de Dios (PO 7a). Por consiguiente, el Vaticano II concede al presbiterado un papel activo en el gobierno y marcha de la diócesis (PO 7a).

Contamos actualmente con el Consejo del presbiterio (junta o senado de sacerdotes representantes de la agrupación de todos ellos: PO 7a), pero, como su nombre indica, tiene un papel consultivo; ciertamente, éste es un modo de colaboración y presta una ayuda valiosa al obispo, que resulta así ser el único responsable de la marcha de las Iglesia particular. Hay que dar otro paso, y el Vaticano II ha entreabierto la puerta a la corresponsabilidad en el ministerio pastoral del obispo y de los presbíteros, asentada y derivada de la común participación en la consagración y en la misión 104. Por tanto, se crea entre obispo y presbíteros una relación que se asienta en sólida base teológico-sacramental.

Hemos escuchado al Vaticano II hablar del presbiterio como colaborador del obispo en su tria munera de santificar, enseñar y regir al pueblo de Dios, e incluso de gobierno de la diócesis ${ }^{105}$. Esto implica un papel del presbiterio más activo que la participación con el simple consejo. Esto está exigiendo un paso adelante en la relación obispo-presbiterio106. Entonces podríamos hablar de un presbiterio adulto por cuanto es corresponsable en su papel

103 Los presbíteros son colaboradores del orden episcopal para cumplir la misión apostólica confiada por Cristo (PO 2b), y están unidos jerárquicamente de diversos modos con el obispo (PO 5a), los presbíteros a quienes los obispos tienen como colaboradores y consejeros necesarios para el ministerio y oficio de enseñar, santificar y apacentar al pueblo de Dios (PO 7a), y el concilio habla de esa ayuda de los presbíteros al obispo en el gobierno de la diócesis (PO 7a).

104 Además de la Nota anterior, el concilio nos dice: Los sacerdotes están adscritos al cuerpo episcopal por razón del orden y del ministerio (LG 28b), y tienen participación del ministerio episcopal, que se les confiere por el sacramento del orden y la misión canónica (PO 7b).

105 Recordemos, por otra parte, que corresponde también al presbítero no solo santificar y enseñar a los fieles, sino también apacentar a los fieles (LG 28a), pues rigen la porción de la grey del Señor a ellos encomendada (LG 28b), gobiernan y sirven a su comunidad (LG 28d).

106 El Vaticano II ha entreabierto las puertas. Es significativo que hable de un solo presbiterio, dedicado a diversas ocupaciones (LG 28b), o sea, con responsabilidad polivalente, en lo que se debe incluir la corresponsabilidad en la marcha de la diócesis. 
activo. En consecuencia, las líneas directrices de la Iglesia particular en todas las vertientes de la misma deberían ser trazadas por el presbiterio, que no se puede limitar a aconsejar al obispo. Debemos reconocer con gusto que se ha dado un paso sobre el papel asignado al presbiterio con la creación del Colegio de consultores, que tiene funciones deliberativas. En resumen, la comunión jerárquica se entiende aquí en clave teológica, no prevalentemente jurídica, por lo que se traduce en colaboración-corresponsabilidad pastoral y no en relación de vasallaje. El obispo, cabeza indiscutible del presbiterio, no puede ignorar al cuerpo presbiteral formado por los sacerdotes, más aún, debería ser el primero en conceder el valor y el papel que tiene el presbiterio debido al sacramento del orden. Hoy el magisterio comienza a respirar también estos nuevos aires ${ }^{107}$.

La teología del presbiterio afecta también a la vida concreta del presbítero. Éste no se puede entender como una isla, el concilio no lo considera pastoralmente aislado de los demás sacerdotes (PO 7c), ni puede desentenderse del trabajo pastoral de los otros presbíteros por más que sea muy diferente del suyo. Desde otro ángulo, la relación de cada presbítero y su responsabilidad pastoral no se pueden limitar a dar cuenta de ello solo al obispo, sino que deberá hacerlo también de cara al presbiterio, a esa fraternidad que forma con los demás co-presbíteros.

\subsection{Episcopado y presbiterado}

\subsubsection{Historia de una relación accidentada}

La historia nos habla de un itinerario de encuentros y desencuentros entre el episcopado y el presbiterado, con etapas de confrontación y otras de armonía, pero siempre en una relación dialéctica.

La postura tradicional durante siglos, que llega a las puertas del Vaticano II, entiende el sacerdocio ministerial a partir de la noción común de sacerdocio presente en las religiones. En base a este presupuesto, obispo y presbítero no se distinguen en cuanto sacerdotes, más concretamente, en cuanto ministros del culto. Comparten la potestas ordinis. La diferencia entre ellos venía vía potestas iurisdictionis, o sea, por la diversidad de competencias: al obispo

107 Entre el obispo y su presbiterio existe una relación fundada en el sacramento del orden. De modo que los mismos presbíteros hacen presente al obispo, de alguna manera, en las reuniones locales concretas de los fieles, toman parcialmente sus oficios y solicitud y los ejercitan con cuidado cotidiano. Por ello, entre el obispo y su presbiterio deben existir relaciones de amistad y llenas de confianza (Sínodo extraordinario de los Obispos de 1985, El Vaticano II, don de Dios. A los veinte años del final del concilio, "Relación final" II.C.6). 
se le asignan roles que no tiene el presbítero108.

El concilio Vaticano II va a dar un vuelco al tema. Por una parte, enseña oficialmente por primera vez la sacramentalidad del episcopado, con la consiguiente colegialidad del mismo (LG 21.22), un avance teológico decisivo, y, para algunos, el principal del Vaticano II, hito basilar de la renovada teología del episcopado. Por otra parte, y consecuentemente, se describe al episcopado en un pasaje fundamental como plenitud del sacramento del orden, Ilamado en la práctica litúrgica de la Iglesia y en la enseñanza de los santos Padres sumo sacerdocio, cumbre del ministerio sagrado (LG 21b). Con esto, se ha rebasado totalmente la perspectiva de Trento, se ha argumentado teológicamente y no por vía de jurisdicción al determinar en el sacramento la raíz del ministerio del episcopado. En base a esta doctrina, el presbiterado debe entenderse ahora teniendo en cuenta este supuesto episcopal, es decir, aquello que es plenitud del sacramento del orden y cumbre del ministerio. La teología actual trabaja, de forma prácticamente unánime, dentro de estas coordenadas: el episcopado es el presupuesto necesario teológicamente para el presbiterado ${ }^{109}$.

Pero esto acarrea consecuencias serias no previstas en principio. Hay que precisar bien de qué relación se trata entre episcopado y presbiterado, para evitar que éste consista fundamentalmente y se defina como dependencia y subordinación al episcopado; de hecho, el crecimiento de la teología del episcopado ha supuesto una disminución de la figura del presbiterado. Con esta visión, queda eclipsado el papel del sacramento del orden en la determinación de la naturaleza de la función profética y real del presbiterado, pues no es presentado como fuente y raíz, pasando el episcopado a ser esa fuente.

Esta situación nos obliga a hacer algunas precisiones. Lo haremos desde dos perspectivas:

a) Hay que distinguir entre entender el presbiterado 'a partir' del episcopado y entenderlo 'a la luz' del episcopado. No se trata de una sutileza, sino de una precisión fundamental porque afecta a la naturaleza del presbiterado. Entender el presbiterado a partir del episcopado significa que éste es la fuente y raíz, y esta conclusión es muy grave porque suplanta la única y verdadera fuente del presbite-

108 Así zanja Trento la superioridad del obispo sobre el presbítero. El otro camino para establecer esta superioridad sería la diversidad de grados o jerarquía en el sacerdocio (DS 1776).

109 La siguiente frase de un teólogo puede resumir la situación: No se funda el presbiterado directamente, sino a través del episcopado, que, a su vez, se fundamenta en la sucesión apostólica (R. Blázquez, La Iglesia del Vaticano II, Sígueme, Salamanca 1988, 120; cf. LG 20c; 21b; 28a; PO 2a.b). 
rado que es el sacramento del orden, como repite incansablemente el concilio ${ }^{110 .}$.

El problema planteado hay que resolverlo, a diferencia de Trento, desde la teología y no desde el derecho canónico, y es lo que ha esbozado el Vaticano II111. ¿Cómo conjugar el papel que el mismo concilio asigna al episcopado respecto del presbiterado y, por otra parte, el papel del sacramento del orden para determinar la naturaleza del presbiterado? El Vaticano II no aborda directamente el tema que acabamos de plantear, pero creemos que sí ofrece suficiente base para afrontarlo.

Avanzamos una propuesta de solución. Éste puede venir por la fórmula: el presbiterado entendido 'a la luz' del episcopado (no a partir del episcopado) ¿Qué se quiere decir con ello? Nos vamos a inspirar en el mismo Vaticano II para adoptar la metodología que emplearemos, recurriendo al cambio operado por el concilio en la relación del episcopado con el primado. Esta relación es la que trata expresamente el concilio. En esta relación, la postura clásica asignaba al sacramento del orden el papel común al obispo y al papa en la función sacerdotal, pero las funciones episcopales de enseñar y de regir al pueblo de Dios no se derivaban del sacramento del orden, sino del papa; éste era la fuente de tales funciones, que otorgaba a los obispos. Aquí entra el giro profundo del Vaticano II: el sacramento del orden es la fuente y raíz de todos los ministerios episcopales: La consagración episcopal, junto con el oficio de santificar, confiere también los oficios de enseñar y de regir (LG 21b). No es el papa la fuente de los ministerios de enseñanza y de gobierno, sino el sacramento.

Hasta aquí la enseñanza expresa del Vaticano II. Pero la teología se propone ahora: a la luz de esta doctrina medularmente conciliar,

110 Quizá no resulte ociosa esta precisión teológica que orille el eventual peligro de episcopalismo. En efecto, hay que dejar bien sentado que es el sacramento del orden la raíz del presbiterado y no el episcopado. Por ello, habría que entender el presbiterado distinguiendo su raíz, que es sacramental, y su funcionamiento o ejercicio, en lo que depende del episcopado como colaborador, como ya expusimos antes.

111 En el concilio se resalta la dependencia del presbiterado respecto del episcopado pero insistiendo que es en el ejercicio del ministerio, porque la raíz o fuente del presbiterado es la sacramental, que es, en nuestra opinión, el criterio para discernir la teología del presbiterado en el concilio. Éste no llegó a una claridad total para armonizar ambos datos. Esto exige un examen minucioso de los textos del Vaticano II, que he abordado con cierta extensión en dos trabajos recientes con el título: ¿Qué es el presbitero? en Seminarios 181 (2006) 359-390 y 182 (2006) 443-484. 
podemos avanzar en la reflexión teológica y, pari modo, aplicarla análogamente a la relación del obispo con el presbítero. El episcopado no es la raíz del presbiterado, sino que el obispo es el ministro ordenante o instrumento para confeccionar el sacramento del orden, pero la única fuente y raíz del presbiterado es el sacramento del orden. Un texto conciliar entre muchos que podían aducirse: Los presbiteros, en virtud del sacramento del orden, han sido consagrados verdaderos sacerdotes del Nuevo Testamento, a imagen de Cristo, sumo y eterno sacerdote, para predicar el Evangelio, apacentar a los fieles y para celebrar el culto divino (LG 28a). Es decir, los tria munera del presbítero que constituyen su quehacer peculiar (PO 13) proceden del sacramento. En una palabra, y dentro siempre del concilio, lo que se afirma expresamente del episcopado respecto del primado puede mantenerse, pari modo y de forma indirecta, del presbiterado respecto del episcopado. Este punto es capital para la elaboración de una genuina teología del presbiterado, que no puede gravitar como su epicentro sobre la subordinación y dependencia del episcopado, sino sobre el sacramento del orden.

b) Segunda perspectiva. Cuando hoy se afirma que el presbiterado hay que entenderlo desde el episcopado, hay que precisar el sentido de este desde. Éste no se mueve en el plano ontológico, sino en el operativo. En efecto, hay que distinguir dos planos: el del ser y el del actuar. Si nos preguntamos por la ontología o el ser ministerial, el presbítero depende o nace del sacramento del orden, es, por tanto, obra directa de Dios y solo de él, que se sirve del ministerio instituyente del obispo, pero si nos preguntamos por la actuación o el ejercicio ministerial, el presbítero depende o está bajo la autoridad del obispo, expresada en la misión canónica; el nihil sine episcopo de Ignacio de Antioquía sigue aquí vigente. Ésta creemos que es la postura del Vaticano II.

He aquí una tarea abierta en orden a una genuina teología del presbiterado.

\subsubsection{Sacerdos secundi ordinis}

Otro modo de ver la relación entre episcopado y presbiterado es a través del prisma de los diversos grados del sacramento del orden. Cada ministerio ordenado participa del sacramento en el grado propio de su ministerio112. El grado subordinado del presbítero se refiere de ordinario en el concilio a la relación del presbítero con el obispo en el nivel del ejercicio del ministerio, no

112 La terminología del concilio: plenitud en el episcopado (LG 21b; 26a), en grado subordinado en los presbíteros (PO 2b) y grado inferior en el diaconado (LG 29a; 41d). 
en el de la ontología presbiteral. Una antiquísima expresión habla de sacerdocio de segundo grado113; el concepto se encuentra ya en Orígenes, es generalizado en la liturgia gracias a Hipólito en la Traditio apostolica y de ahí pasa al Ritual de Ordenación, hasta hacerse común en el siglo V. A Rabano Mauro se debe que pase a ser doctrina común en la escolástica114. Lo que sí podemos afirmar es que cada uno de los ministerios ordenados es completo en sí mismo, que el ministerio inferior no tiene una deficiencia que cubre el ministerio superior a él.

No olvidemos que el lenguaje no es inocente.

\subsection{Equilibrio entre los munera del sacerdote}

Hay diversas dimensiones o vertientes en el ministerio sacerdotal. La historia nos habla de prevalencia de alguna de ellas sobre las otras, caracterizando así el sacerdocio ministerial por el tinte o matiz representado por el munus dominante. Por otra parte, la teología, incluso la actual, toma un determinado sesgo a partir del munus que se ha elegido como eje o centro.

EI Vaticano II ha trazado las líneas maestras para un equilibrio entre las diversas vertientes: cristológica, eclesiológica y comunitaria del sacerdocio ministerial, o, de otra parte, entre la sacramentalidad y la ministerialidad, ambas de la entraña del sacerdocio. La teología hoy se ocupa de este tema, proponiendo una visión unitaria del ministerio presbiteral, sin exaltar uno de los tria munera a costa de los otros ${ }^{115}$, pero esto no ha sido asumido suficientemente, por lo que hay que intentar una solución integradora que equilibre los extremos, porque solamente así se podrá salvar la riqueza del depósito de la fe $\mathrm{f}^{116}$. La clave de la relacionalidad como concepto para organizar la teología del sacerdocio y el concepto de red de relaciones para definirlo serían

113 Fórmula que no recoge el Vaticano II, y no suena bien a algunos oídos. Conozco algún obispo que la ha omitido en la ordenación. Otras expresiones antiguas: secundi meriti munus, secunda dignitas, sequens ordo por cuanto sigue al episcopado, situando siempre al presbiterado a un nivel inferior al episcopado.

114 No es una definición dogmática, por lo que puede ser modificado en el futuro a la luz del desarrollo de la teología del ministerio ordenado.

115 Sirva como ejemplo G. Greshake, Ser sacerdote. Teología y espiritualidad del ministerio sacerdotal, Sígueme, Salamanca 1965, 83-88. La obra ha sido reeditada notablemente ampliada; ICIM, 346-347.

116 MNA, 100; cf. 110-114. En esta obra, se trata precisamente de hacer justicia a todos los componentes del sacerdocio ministerial, en base a la red de relaciones, que es constitutiva del sacerdocio, y a la clave de la relacionalidad para organizar el tratado sobre el sacerdocio, tema que expusimos anteriormente. 
un medio importante para lograr nuestro objetivo117.

\subsection{Hacia el nuevo tipo de sacerdote}

\subsubsection{Del 'Sumo sacerdote' al 'Siervo de Yahvé'}

El tema veterotestamentario del Siervo de Yahvé encuentra un amplio eco en el Nuevo Testamento y, quizá lo más llamativo es comprobar cómo Jesús se identifica con esta figura. Se convierte así en un registro muy significativo a través del cual debemos ver la existencia sacerdotal de Cristo y la conciencia que él tenía de ello. La figura del Siervo es fundamental para entender el sacerdocio de Cristo. Los evangelios no aplican a Cristo títulos sacerdotales, ni nos lo presentan en acciones sacerdotales rituales, pero interpretan su muerte como un sacrificio y presentan toda su vida en clave de Siervo de Yahvé.

Aquí detectamos precisamente una laguna en la mentalidad tanto del pueblo de Dios como de la teología. Se ha priorizado la figura del Sumo sacerdote, originando una teología sacerdotal de la grandeza, la dignidad e incluso de los privilegios, dejando en la penumbra la figura del Siervo de Yahvé. Éste, precisamente, es el que nos ofrece la plataforma para una teología sacerdotal del servicio, la humildad y la entrega total, en una palabra, la teología a que nos incita la doctrina del Vaticano II, camino hacia el nuevo tipo de sacerdote.

\subsubsection{Una búsqueda secular}

La búsqueda del nuevo tipo de sacerdote se ha dado siempre que la Iglesia ha tomado nueva conciencia de sí misma y que el contexto socio-cultural ha sufrido profundos cambios. Cuando esto ocurre, se genera una nueva situación, indispensable plataforma y caldo de cultivo para entender al sacerdote. Esto es, precisamente, lo que ha ocurrido con el Vaticano II, y de ahí surge el imperativo de buscar un nuevo tipo de sacerdote.

Ningún ministerio es lo que era antes del concilio. Por lo que se refiere al sacerdote, tiene una nueva relación con el obispo, con los demás sacerdotes, con los laicos y con el mundo118. Vamos a fijarnos, por vía de ejemplo, en el capítulo del nuevo tipo de sacerdote.

En primer lugar, el sacerdote hoy se debe entender en una Iglesia cuerpo ministerial o toda ella ministerial, lo que supone la superación de la reducción

117 PDV habla del aspecto esencialmente relacional de la identidad del presbítero... No se puede definir la naturaleza y la misión del sacerdocio ministerial si no es bajo este multiforme y rico conjunto de relaciones (N. 12c).

118 Cf. MNA, 529s. 
y monopolio clerical119. Se trata de un nuevo modo de estar en la Iglesia'20. La postura del magisterio es hoy nítida, superando barreras seculares. Hay verdaderos ministerios eclesiales no procedentes del sacramento del orden: Al lado de los ministros con orden sagrado, en virtud de los cuales algunos son elevados al rango de presbiteros y se consagran de modo peculiar al servicio de la comunidad, la Iglesia reconoce un puesto a ministerios sin orden sagrado, pero que son aptos para asegurar un servicio especial a la Iglesia121.

\subsubsection{Perfil del 'nuevo tipo' de sacerdote}

El ministerio sacerdotal hay que concebirlo hoy constelado de otros ministerios edificadores de Iglesia, con tareas específicas aunque complementarias entre sí122. Los obispos franceses se expresan en estos términos: El presbítero permanecerá un don de Dios a su pueblo, un don inestimable e irreemplazable, pero en una Iglesia en la que los presbíteros no actúan solos,

119 Quienes ejercen los diversos ministerios eclesiales en las comunidades locales conforman el cuerpo ministerial y traducen asi operativamente a una Iglesia toda ella ministerial, sin que ninguno de los ministros pueda considerarse a sí mismo como el representante o totalizante de todo el ministerio de la Iglesia, que como tal no llega a su expresión total sino en el diversificado cuerpo ministerial" (Secretariado General del CELAM, "Ministerios eclesiales en América Latina en Seminarios 23 (1977) 268) Cf. Conferencia Episcopal Francesa, Tous responsables dans l'Eglise. Le ministére presbytéral dans l'Eglise tout entiére ministérielle, Centurion, Paris 1973. Trad. española: Sal Terrae, Santander 1975; Commission Internationale de Théologie, Le ministére sacerdotal. Rapport, Cerf, Paris 1971: el capítulo III tiene por título: L'Eglise, peuple de Dieu tout entier sacerdotal.

120 Los presbíteros siguen siendo absolutamente necesarios, pero deben estar de otra forma en la Iglesia y en la tarea de la evangelización. Al asumir responsabilidades muchos bautizados, cambia felizmente la vida del presbítero en la medida en que se presta a la nueva distribución de tareas, las promueve y cultiva, lo que hace de él un modelo o un acompañante de los fieles más que un gestor de una empresa religiosa (Conferencia Episcopal Francesa, Ministerio y vida de los presbíteros diocesanos en Seminarios 112 (1989) 245).

121 Pablo V, Exh. apost. Evangelii nuntiandi, n. 73; cf. Id., Motu proprio Ministeria quaedam, 1972, donde se instituyen ministerios laicales; L. Rubio Morán-V. Hernández Alonso, Los ministerios laicales en el magisterio actual de la Iglesia en Seminarios 93-94 (1984) 427-491.

122 El cumplimiento efectivo del ministerio presbiteral depende hoy en nuestro medio de que el presbítero sepa rodearse de nuevos ministros y sepa coordinar, en el ámbito de su competencia, la variada actividad ministerial que él monopolizó hasta ayer por fuerza principalmente de las circunstancias (Secretariado General del CELAM, a. c. en Nota 118, p. 272). 
sin el pueblo de los cristianos ${ }^{123}$.

A partir de ahora, la teología ha de entender el quehacer del sacerdote en el horizonte de los diversos ministerios que el Espíritu Santo suscita en la Iglesia. No se trata de entrar en competencia entre ministerios ordenados y no ordenados, sino que se trata de que cada uno de ellos ocupe el lugar y preste su servicio en el marco del pleroma eclesial. Los términos clave que hay que conjugar desde ahora serán complementariedad y corresponsabilidad pastoral de ministerios en la única misión de la Iglesia, bajo los siguientes principios trazados por el concilio: En la Iglesia hay diversidad de ministerios, pero unidad de misión (AA 28; 33a) y en el conjunto del cuerpo vivo, el Cuerpo místico de Cristo, no hay miembros que se comportan de forma meramente pasiva, sino que todos participan de la actividad vital del cuerpo (AA 2a; cf. Ef 4, 16; PO 2; AA 10) Todo ello obliga a repensar el ministerio sacerdotal en el nuevo contexto eclesial y pastoral, en una Iglesia que es comunidad de ministerios (LG 30; cf. AG 21a), en una Iglesia pluriministerial. La teología actual toma conciencia de ello: Los nuevos servicios y ministerios eclesiales en su relación con el ministerio presbitera/124, o el ministerio presbiteral en una Iglesia toda ella ministeria/125. En efecto, toda la Iglesia es sujeto auténtico y primario de la misión salvífica eclesial y el individuo -ya sea papa, obispo, sacerdote o laico- solo puede actuar en comunión con el todo y como órgano del conjunto ${ }^{126}$.

Está en marcha un nuevo tipo de presbítero, cuyo perfil describimos de la siguiente manera:

En determinados ambientes eclesiales, que han aceptado y puesto en práctica la diversificación del ministerio, comienza a delinearse un nuevo tipo de presbítero. No es un producto de laboratorios teológicos, aunque la teología no sea extraña a su alumbramiento, sino el resultado de una praxis y de una nueva conciencia eclesial y misionera de determinadas comunidades. Es un tipo de presbitero que sabe rodearse de múltiples ministros del evangelio, que entiende y pone en práctica la diversidad de tareas y responsabilidades, que se constituye en el primer promotor de nuevos ministerios, que coordina los esfuerzos de otros agentes de evangelización; un nuevo tipo de presbítero, 'el llamado que llama' y vela sobre los llamados, se constituye en promotor y catalizador de diversos ministerios, con los que comparte la responsabilidad de la misión eclesial; con frecuencia se deberá constituir en

123 Ministerio y vida de los presbiteros diocesanos en Seminarios 112 (1989) 240-241.

124 Formulación de la Asamblea de Seminarios Mayores Alemanes.

125 Subtítulo de la obra de la Conferencia Episcopal Francesa en Nota 118.

126 W. Kasper, Nuevos matices en la concepción del ministerio sacerdotal en Concilium 43 (1969) 379; cf. A. Antón, Primado y colegialidad, Madrid 1970, 40-41. 
'ministro itinerante' y en una especie de superintendente de otros ministerios que se ejercen en un nivel más local, en el mismo corazón de determinados campos apostólicos o de comunidades cristianas ${ }^{127}$.

Va cuajando la idea de los ministerios plurales en la Iglesia, que conoce un florecimiento ministerial 128 .

Los obispos latinoamericanos son bien explícitos: De hecho, varias de las tradicionales ocupaciones de los ministros ordenados pueden ser servidas hoy por el ministerio de los laicos: visitar a las familias, anunciar y celebrar la palabra, distribuir la sagrada comunión en las celebraciones eucarísticas, visita a los enfermos, preparar los bautismos y los matrimonios, impartir catequesis, ejercer el ministerio de la caridad y la atención asistencial en la Iglesia, animar la pastoral en varios niveles, etc. ${ }^{129}$.

Algo se mueve en el mundo de los presbíteros, un difuso malestar como si se proyectara sobre el futuro de su ministerio un aura de inseguridad, desconfianza o menor estima, viendo en la irrupción de los ministerios laicales una competencia que les arrebata espacios y tareas hasta ahora ocupados por ellos. Los presbíteros necesitan una conversión a la nueva realidad eclesial-ministerial, porque el fututo al que aludimos ya ha comenzado.

La nueva concepción ministerial de la Iglesia no se debe a razones coyunturales como puede ser la escasez de sacerdotes, sino principalmente a razones eclesiológico-pastorales, en definitiva, se debe a la naturaleza de una Iglesia toda ella ministerial y a la evangelización que se le ha confiado.

127 MNA, 90.

128 Pronto se comienza a aglutinar los ministerios en torno a unos núcleos o ejes básicos de la acción de la Iglesia, servicios en torno a la palabra, al culto, a la unidad, a la dirección de la comunidad y, aunque con menos frecuencia, en torno a la caridad y a la asistencia. Los ministerios clasificados y descritos con más precisión son los litúrgicos: lector, acólito, ministro extraordinario de la comunión y los que hacen referencia a la comunidad: presidente de la asamblea, celebradores de la palabra, catequista... (MNA, 93). Cf. D. Borobio, Ministerio sacerdotal y ministerios eclesiales, DDB, Bilbao 1982; L. Rubio Morán, Presencia y urgencia de ministerios nuevos en la Iglesia española en Seminarios 23 (1977) 149-183; F. Urbina de Quintana, Hacia una nueva figura histórica del ministerio. Vocaciones para una comunidad misionera, EDICEP, Valencia 1974; J. Miller, Para poner remedio a la falta de sacerdotes en Cristo al Mundo 18 (1973) 306-311; E. Royón Lara, Los ministerios eclesiales. Nuevas perspectivas en Seminarios 21 (1975) 421-436). Habría que remontarse a los orígenes para abordar el pluralismo ministerial: cf. A. Lemaire en Nota 99.

129 Secretariado General del CELAM, Ministerios eclesiales en América Latina en Seminarios 23 (1977) 268. En pp. 270-271 se habla de nuevos servicios en el ministerio de la palabra, del culto, de la unidad y de la asistencia. 
Los seglares están llamados a contribuir con todas sus fuerzas al despliegue de la actividad y de los servicios de la Iglesia total, no precisamente para suplir la actual falta de sacerdotes, sino en virtud de la tarea que les impone la realización de su envío ${ }^{130}$. Está en juego el nuevo tipo de Iglesia por el que apostó el Vaticano II.

Si tenemos fe en el Señor de la Iglesia y en la acción de su Espíritu, y contando con el aporte de los responsables oficiales de la Iglesia, no resulta utópico pensar prospectivamente en un panorama ministerial muy distinto del tradicional, acorde con las necesidades de la evangelización. La Iglesia de nuestros días tiene la palabra, y sabe que no trabaja en un terreno baldío, sino en un campo abonado por el Espíritu Santo, motor y alma de todo ministerio (1 Cor 12, 4-14.28-30; Rom 12, 6-8; Hech 1, 8; 2, 17...).

\subsection{Hacia una teología renovada del presbiterado}

Abordamos ahora un tema que en realidad se planteó inmediatamente después del Vaticano II: entender de forma nueva el presbiterado, búsqueda del nuevo tipo de sacerdote sobre el que acabamos de reflexionar. Un sacerdote situado, en armonía y complementariedad con otros ministerios eclesiales (referencia al laicado), con un nuevo tipo de relación con el obispo (referencia al episcopado), con un nuevo modo de estar en la sociedad (referencia al mundo). Pero, sobre todo, se busca una teología del presbiterado con consistencia teológica propia, y no meramente dependiente del episcopado. $O$ sea, lo que ha sido en buena parte una de las causas de la crisis, al sentirse el presbítero entre un episcopado y un laicado crecidos en el concilio, debería ser ahora causa de la genuina teología del presbiterado abordada en nuevas perspectivas.

La confianza en el Señor nos proporciona la seguridad de que la Iglesia hallará el camino apropiado, como ocurrió en épocas pasadas, que no siempre fueron fáciles. Desde el principio, el Señor dejó en manos de la Iglesia la configuración, regulación y organización del ministerio. El creyente sabe que el futuro es para quienes escuchan lo que el Espíritu dice a su Iglesia (Ap 2, 29), y nuestra seguridad en la Iglesia procede de que, como nos asegura el Vaticano II, Dios, que habló en otros tiempos, sigue conversando con la Esposa de su Hijo amado y el Espíritu Santo, por quien la voz viva del Evangelio resuena en la Iglesia, y por ella en el mundo entero, va introduciendo a los fieles en la verdad plena (DV 8c). El que llamó y sigue llamando no abandonará a quienes se ponen al servicio de su plan de salvación para el mundo. Hoy no podemos buscar refugio en fórmulas del pasado que ofrezcan seguridad, ni resignarnos pasivamente en tanto llegan tiempos de bonanza. El imperativo de Pablo nos interpela: Reaviva el carisma de Dios

130 Conferencia Episcopal Alemana, El ministerio sacerdotal. Estudio bíblico-dogmático, Sígueme, Salamanca 1971, 42. 
que está en ti por la imposición de las manos (2 Tim 1, 6).

\subsubsection{Teología del sacerdocio 'en camino'}

Nos situamos en el proceso de búsqueda que comenzó con los primeros pasos de la Iglesia. Se han dado momentos que han sido verdaderos hitos en la historia de la teología del sacerdocio, pero la Iglesia no ha considerado ninguno de estos momentos como definitivo. La teología del sacerdocio ha estado siempre en camino.

El Vaticano II ha significado un punto de llegada para la teología del sacerdocio ministerial, pero es también, y no en menor medida, un punto de partida desde donde se debe continuar el proceso o itinerario en la elaboración de esta teología. El concilio ha sentado bases sólidas y ha abierto nuevos horizontes, con lo que nos ha convocado a una tarea que el concilio no pudo o no supo llevar a cabo, dejándonos ante la empresa y el reto de una renovada teología del ministerio sacerdotal.

En trabajos anteriores de los últimos años, nos hemos ocupado, por una parte, de la secular pregunta: ¿Qué es el sacerdote?131, y, por otra parte, hemos esbozado unos aportes a modo de aproximación a una genuina teología del presbiterado132, que, en nuestra opinión, está por hacer. La plataforma indiscutible sobre la que construir la renovada teología del sacerdocio es el Vaticano II, teniendo en cuenta principalmente estos datos:

- La eclesiología de comunión y la teología del ministerio eclesial emanados del concilio, con el profundo giro que llevó a cabo en estas temáticas.

- Numerosos datos o elementos teológicos sobre el sacerdocio ministerial, que, como disiecta membra, jalonan los documentos conciliares, pero que no han sido organizados de forma que constituyan un sistema. Recordemos lo advertido al principio de este trabajo: el tema del sacerdocio ministerial no figuraba en la agenda inicial del concilio, y se incorporó cuando el concilio estaba ya caminando ${ }^{133}$, el principal documento sobre nuestro tema, PO, se trabajó fundamentalmente en las intersesiones del concilio como mostramos al comienzo de este trabajo cuando expusimos la historia del

131 MNA, 27-62 y los dos trabajos sobre el presbítero de la Nota 110.

132 MNA, 403-453; ICIM, 289-362.

133 El presbítero como tal y su puesto específico en la sinfonía del los ministerios eclesiales se ha planteado con honda preocupación en los años que siguieron al concilio, con conciencia de haber sido una temática relegada" (Cf. C. Giaquinta, El colegio presbiteral. Apuntes de ayer y de hoy para una comprensión del sacerdocio en Teología 6 (1965) 2-5) 
documento.

- La teología del episcopado, fruto espléndido del concilio, obliga a repensar teológicamente el presbiterado, debido a la necesaria relación teológica entre ambos ministerios ordenados. Se necesita buscar un mayor equilibrio entre estos ministerios, por una parte, y el laicado por otra ${ }^{134}$.

Este nueva relación no puede significar que la esencia del presbiterado sea la subordinación o dependencia del episcopado por ser éste plenitud del sacramento del orden y cumbre del ministerio sagrado (LG 21b); el presbítero no puede reducirse a ser mero colaborador del obispo, sino que la esencia o naturaleza sacerdotal debe gravitar sobre el sacramento del orden, como hemos expuesto en anteriores trabajos ${ }^{135}$. El sacerdote es y actúa por sí mismo como representante sacramental de Cristo, y ello como fruto del sacramento del orden y no por derivación o concesión del ministerio episcopal.

- De todo esto se deduce que la clave fundamental para expresar la relación entre el presbiterado y el episcopado no es la obediencia de aquél a éste, sino la corresponsabilidad o solidaridad apostólica de quienes comparten sacramento, sacerdocio y misión, y cuya mejor expresión teológico-pastoral es el presbiterio. El mismo concilio, en un pasaje clarificador, califica la obediencia sacerdotal de penetrada de espíritu de cooperación y declara que la obediencia sacerdotal se funda en la participación misma del ministerio episcopal (PO 7b).

Al tratar, pues, de una teología del presbiterado con consistencia propia, con identidad teológica propia, digamos, un presbiterado con mayoría de edad teológica y con personalidad específica, y que cuente como fundamento indiscutible el sacramento del orden y sea corresponsable de la misión apostólica por derecho propio, todo esto exige una renovación profunda. Con este propósito, hemos propuesto unas pautas que recogen los mejores aportes del Vaticano II, del magisterio y de la teología postconciliar.

\subsubsection{Apuntes para la renovada teología del presbiterado136}

Nos vamos a limitar al enunciado de unas pautas, a modo de tesis sobre las que asentar la nueva teología del presbiterado.

$1^{\circ}$. Sacerdotes de Jesucristo. Raíz y paradigma cristológico del sacerdocio ministerial, a partir de la Carta a los Hebreos. Jesucristo, y solo él, es la realización plena del diseño
134 Cf. ICIM, 289.
135 Cf. Nota 130.
136 Cf. ICIM, 352-361. 
de Dios sobre el sacerdocio y, por tanto, la referencia primera.

Configuración peculiar con Cristo Cabeza, Pastor y Esposo de la Iglesia, que nos remite al necesario componente sacramental y eclesial.

$2^{\circ}$. Claves teológicas. Claves que atraviesan transversal y simultáneamente el sacerdocio: sacramentalidad, ministerialidad y relacionalidad.

Se muestra así la riqueza del sacerdocio, se logra un planteamiento equilibrado entre sus componentes y se evita con ello, sobre todo gracias a la relacionalidad, caer en reduccionismos que enfatizan una vertiente a costa de las otras.

$3^{\circ}$. Tradición y misión apostólica. El sacerdote es incorporado a la estructura apostólica de la Iglesia, por cuanto se le constituye en garante, testigo, continuador y portador inmediato de la misión apostólica para la comunidad. Ésta encuentra en el sacerdote el eslabón que la remite al origen apostólico.

$4^{\circ}$. Representación sacramental de Cristo. Ésta es la fórmula teológica más exacta para expresar lo que es el sacerdote en su ser y en su ministerio: ser la representación sacramental de Cristo Cabeza, Pastor y Esposo de la Iglesia, por lo que es habilitado para actuar in persona Christi e in nomine Ecclesiae.

El sacerdocio ministerial tiene entidad propia y valor por sí mismo en virtud del sacramento del orden, o sea, cuenta con un aval sacramental.

$5^{\circ}$. Teología del presbiterio. El presbítero es co-presbítero. El presbiterio es una realidad teológico-sacramental, y la mejor expresión del carácter colegial del sacerdocio ministerial.

El presbiterio es una fratemidad sacramental, el sacramento inserta al presbítero en la comunión con el obispo y con los demás presbíteros, encarna el ministerio ordenado solidario y corresponsable, por lo que debería ser la instancia ministerial primera en la Iglesia particular.

En el presbiterio confluyen las vertientes sacramental, pastoral y vital-existencial del sacerdote.

$6^{\circ}$. Relación con la teología del episcopado. La teología del presbiterado tiene necesariamente en el trasfondo, según la doctrina del Vaticano II, la teología del episcopado.

Definir al presbítero como colaborador del orden episcopal es una verdad que hay que mantener, pero necesita algunas precisiones para no reducir la ontología del presbiterado a mera colaboración con el obispo, y para no hacer derivar del episcopado los munera del presbiterado; esto significaría dejar en la penumbra el papel irreemplazable del sacramento del orden.

El presbiterado no se puede entender después del Vaticano II sin el episcopado, pero la mejor manera de expresarlo no es con la fórmula: colaborador del obispo, sino que consideramos más correcto decir a la luz de lo expuesto en este trabajo que está ministerialmente asociado al obispo, cabeza del presbiterio, pues obispo y presbítero comparten orden, sacerdocio y misión. 
Hay que elaborar la renovada teología del presbiterado no a partir del episcopado, como si éste fuera su fuente, sino a la luz del episcopado tal como ha sido diseñada su teología en el Vaticano Il.

$7^{\circ}$. Cauces y organismos colegiales. Los principios teológicos de participación y corresponsabilidad deben ser hoy moneda corriente en la Iglesia. Son la vertiente operativa del principio comunión, es la solidaridad en el ejercicio del ministerio.

EI Vaticano II ha hecho uno de sus conceptos clave el tema de la sinodalidad, que afecta a todas las fibras de la Iglesia, y que, por su propia dinámica, desemboca en órganos colegiales. El presbiterio es el concepto clave y el mejor cauce colegial en la acción conjunta del obispo y los sacerdotes, y el mejor medio para superar el individualismo ministerial.

$8^{\circ}$. Espiritualidad propia. El tema de la espiritualidad debe ocupar el lugar teológico que le corresponde en la teología renovada del presbiterado.

El presbítero tiene una espiritualidad propia y específica, derivada del sacramento del orden, no es copia ni imitación de la espiritualidad del religioso o del laico.

El eje de esta espiritualidad radica en la estrecha relación entre identidad sacerdotal y espiritualidad sacerdotal, que corren la misma suerte. El fundamento de esta espiritualidad específica es el sacramento del orden, que matiza toda la vida espiritual del sacerdote.

La consecución de la perfección la logra el sacerdote en el ejercicio del ministerio. E aporte del Vaticano II en este campo ha sido decisivo.

$9^{\circ}$. Hacia la ontología del presbiterado. Caminamos hacia una teología del presbiterado como ministerio sacerdotal específico.

Hay que revalorizar lo propio y distintivo del presbítero, buscamos un presbítero con entidad propia, con rostro que lo especifique como uno de los ministerios ordenados, en comunión con los demás ministerios eclesiales, pero desde su propia identidad.

$10^{\circ}$. Bajo el signo de la comunión. Cuando hablamos de propio y específico, tanto al tratar de la ontología como de la misión y espiritualidad del presbítero, no se debe entender como autonomía.

Lo que buscamos es la personalidad propia, emanada del sacramento del orden. El presbiterado es un ministerio propio y distinto, que actúa necesariamente bajo el signo de la comunión con el episcopado, que es otro ministerio nacido también del mismo sacramento del orden, y con el laicado, a partir del sacramento compartido del bautismo.

La teología del presbiterado es hoy una teología en camino, un tema abierto y sometido a una intensa búsqueda, pendiente de una respuesta teológica satisfactoria que haga justicia a su identidad. La solución que se le dé contribuirá sin duda a afrontar la crisis sacerdotal. El Vaticano II inició el camino de renovación, elaboró materiales muy valiosos, sugirió pautas... por lo que es necesariamente para nosotros referencia obligada, pero no levantó el edificio de la genuina teología del presbiterado, de la que se ha ocupado el magisterio y la teología postconciliar, pero que sigue siendo asignatura pendiente. 